\title{
Hydrochemical impact of construction of the western section of the Hallandsås rail tunnel in Sweden
}

\author{
Fredrik Mossmark $^{1,3}$ (D) Katinka Klingberg Annertz ${ }^{2} \cdot$ Lars O. Ericsson $^{1}$ • \\ Malin Norin ${ }^{1,4}$
}

Received: 1 December 2015 / Accepted: 17 October 2016

(c) The Author(s) 2016. This article is published with open access at Springerlink.com

\begin{abstract}
This paper presents a study of the hydrochemical changes that took place during construction of a section of the Hallandsås rail tunnel in southwest Sweden based on monitoring from spring 2011 to summer 2012. Leakage into the tunnel during construction caused lowering of the groundwater levels, which in turn resulted in a decrease in or absence of base flow in the streams. The water in the streams became dominated by meteoric water during the drawdown periods. Meanwhile, wetlands were aerated, and oxygen could penetrate to oxidise reduced $\mathrm{S}$, releasing acids and $\mathrm{SO}_{4}$. The results for the groundwater in the bedrock differed spatially depending on local geological conditions. In each of the three monitored boreholes, higher redox potentials, higher concentrations of organic matter and lower concentrations of dissolved $\mathrm{Mn}$ and $\mathrm{Fe}$ were observed. In two of the boreholes, oxidation of pyrite, $\mathrm{FeS}_{2}$, present as a fracture mineral, caused the formation of $\mathrm{SO}_{4}$ and acids with subsequent falls in $\mathrm{pH}$ and alkalinity. Leakage into underground constructions generally shortens the residence time of the groundwater significantly. Silicate weathering would thus become less important for the hydrochemistry compared to processes that occur during shorter time frames. As regards the durability of the tunnel, the hydrochemical changes observed in two of the three boreholes indicate a more aggressive environment for several parameters known to increase corrosivity of steel.
\end{abstract}

Fredrik Mossmark

fredrik.mossmark@chalmers.se

1 Chalmers University of Technology, Gothenburg, Sweden

2 Swedish Transport Administration, Borlänge, Sweden

3 Geological Survey of Sweden (SGU), Uppsala, Sweden

4 NCC Sverige AB, Solna, Sweden
The recovery of the groundwater levels occurred rapidly following completion of the waterproofing systems in the Tunnel. However, hydrochemical recovery with regard to major ions and $\mathrm{pH}$ occurred gradually and with an expected duration of several years.

Keywords Tunnels · Groundwater · Hydrochemistry · Durability

\section{Introduction}

Underground constructions are generally subjected to groundwater leakage (Gustafson 2012), and the implications of this have been studied in several underground constructions. Romeriksporten in Norway (Kitterød et al. 2000; Kværner and Snilsberg 2013), the Hsueh-Shan Tunnel in China (Chiu and Chia 2012), and the Bolmen Tunnel in Sweden (Olofsson 1991) are examples of particularly well documented tunnelling projects from a groundwater perspective.

The Hallandsås rail tunnel will form part of the West Coast Line, which connects the City of Lund to the City of Gothenburg in southwest Sweden. To upgrade the standard of the railway, construction of the Hallandsås rail tunnel commenced in 1992. However, progress has been interrupted on two occasions (Jones 2010) due to groundwaterrelated issues. Since 2005, construction of the tunnel has been carried out using a tunnel-boring machine (TBM). Before 2005, construction of the western and eastern tunnels largely took place using regular drilling and blasting. Breakthrough in the eastern tunnel was achieved in August 2010. Construction of the western tunnel using the TBM commenced in 2011 and breakthrough was achieved in September 2013. 
Tunnelling through the Hallandsås Ridge has had a notable impact on the groundwater levels and the hydrochemistry (Borca 2007; Mossmark et al. 2010; Kvartsberg 2013). In most areas, the impact has been limited in terms of drawdown and time period. However, in certain areas along the two tunnels, tunnelling has had a persistent hydrological impact for more than a decade (Mossmark 2010).

The geological, hydrological, and hydrochemical conditions in the Hallandsås Ridge tunnelling project have been monitored continuously by a team of professionals at the Swedish Transport Administration. However, research has also been carried out involving geophysical measurements in relation to hydrogeological conditions (Dahlin et al. 1999; Danielsen and Dahlin 2009; Danielsen and Madsen 2013). Observations regarding engineering geology and hydrogeology from the construction of the eastern tunnel are summarised in Sturk et al. (2011).

\section{Scope of work, objectives, and limitations}

One of the surface water catchments and the underlying bedrock on the Hallandsås Ridge were studied during construction of the western tunnel in 2011-2012. As a part of the study, the following monitoring and evaluation was carried out:

- The water levels and hydrochemistry were monitored in the groundwater in deep, open boreholes in the bedrock and hydrochemistry and flow were monitored in streams.

- The results were evaluated to acquire an understanding of the linked hydrogeological-hydrochemical influence of the tunnelling. The evaluation included a discussion of the mixing of water and hydrochemical processes. In the monitoring and evaluation, the overriding parameters were those that were considered important with regard to degradation of the construction materials in a tunnel as well as those that were of concern regarding the function of tunnel drainage systems.

The study conducted at the Hallandsås Ridge had the following aims:

- Improve the understanding of hydrochemical changes caused by underground constructions.

- Provide input data for an ongoing project aimed at developing methods to predict hydrochemical changes during the construction and operation of a tunnel based on data collected prior to construction.

- Assess the importance of hydrochemical changes related to degradation of construction materials with examples from existing standards and corrosion indices.
The results obtained in this study have been discussed with reference to observations and results from the construction of the Hallandsås eastern tunnel. As part of the study, boreholes made previously in the bedrock were monitored, as well as filter wells in the overburden and existing sampling points for surface water. Further installations were not created, hence the limited shallow groundwater data. The study did not include the sampling of seeping water into the tunnels or monitoring of the unsaturated zone. Biological parameters have been excluded, with the exception of the measurement of the presence of organic matter in the groundwater and ocular observations from the study area. The study also excludes organic groundwater contaminants.

\section{Conditions in the Hallandsås Ridge and in the study area}

The Hallandsås Ridge is located in southern Sweden, approximately $100 \mathrm{~km}$ north of Copenhagen (in Denmark) and $200 \mathrm{~km}$ south of Gothenburg. The climate in the area is classified as a marine west coast climate, i.e. mild with no dry season, warm summers, and moderate seasonality (Kottek et al. 2006). Land use in the areas to the north and south of the ridge, in the vicinity of the tunnel, is dominated by farmland. Approximately $50 \%$ of the Ridge is covered by forest and the remaining areas comprise pasture land and agricultural land. The spatial distribution of forest and land used for grazing/agriculture is shown in Fig. 1.

The Ridge comprises a horst formed along the Tornquist Zone, a tectonic zone that stretches from northwest Europe (the North Sea) to southeast Europe (the Black Sea). There are several horsts and grabens in southwest Sweden, oriented along the Tornquist tectonic zone, as shown in Fig. 1. The horst mainly comprises Precambrian igneous rock, while in the surrounding areas and the grabens the igneous rock is overlain by sedimentary rocks (Lindström et al. 2000).

\section{Geological conditions}

The horst through which the tunnels were constructed is approximately $80 \mathrm{~km}$ long, 5-10 km wide, and its highest point is $226 \mathrm{~m}$ above sea level (Ringberg 2000). The horst consists of crystalline rock, primarily granitic gneiss with dolerite dykes. Amphibolite is also present in the form of intrusions within the gneiss. The dykes are generally oriented in the longitudinal direction of the horst (Annertz, personal communication). The dolerite dykes have an almost vertical dip. The host rock, the granitic gneiss, is generally fractured in the vicinity of the dolerite intrusions with fracture zones on both sides of the almost vertical 


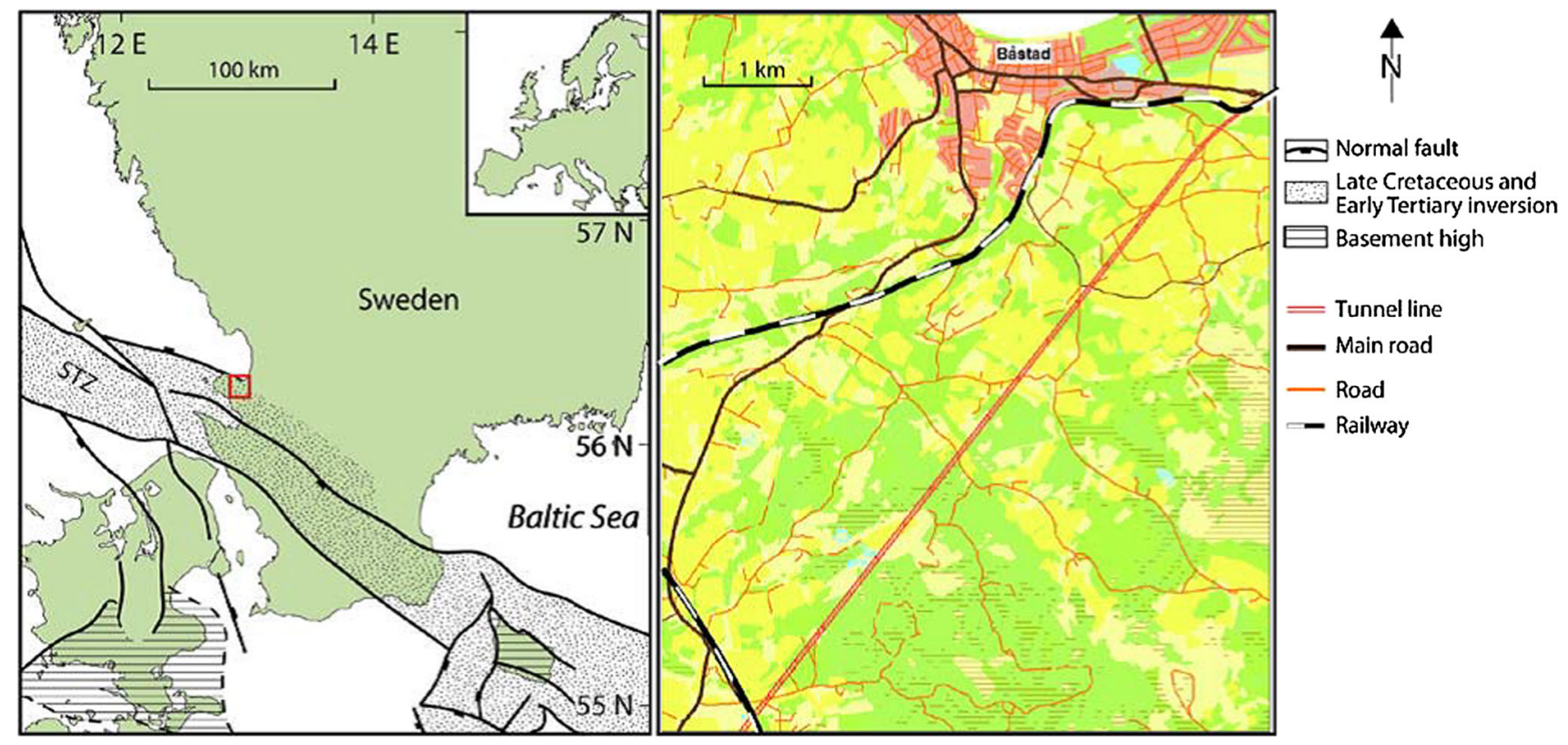

Fig. 1 Location of the tunnel in southwest Sweden (Danielsen 2010). The Hallandsås Ridge is a horst, and its slopes comprise fault lines within the Tornquist Zone (left). The location of the tunnel, the

sheets of dolerite. The dolerite and the granitic gneiss have weathered surfaces and are fairly water-bearing at shallow depth but at greater depth the dolerite dykes have generally few water-bearing fractures (Gynnemo 2009).

The bedrock in the Hallandsås horst comprises rocks formed during the Gothian orogeny, $1.7 \mathrm{Ga}$ (Åhäll and Gower 1997). Several major geological events have shaped the current geological conditions. Hallandsås is defined as being part of the Sveconorwegian orogeny, which occurred between 1.15 and $0.9 \mathrm{Ga}$. At that time, the previously formed bedrock was metamorphosed (Lindström et al. 2000). During the most recent period of the Sveconorwegian orogeny, the bedrock was subjected to tectonic uplift and the main deformation processes changed from being ductile to being dominated by brittle conditions.

The northern and southern slopes of the horst and the dykes are parallel to deformations along the Tornquist Zone, which includes the Hallandsås Ridge (Norling and Bergström 1987). The formation of the Tornquist Zone included repeated tectonic events that have shaped the fractured bedrock of Hallandsås. The brittle deformation regimes have contributed to the fracturing. The weathered surface has been subjected to erosion during the past $100 \mathrm{Ma}$ (Wikman and Bergström 1987) although strike-lift faulting has resulted in previously superficial rock mass occurring at tunnel level at certain locations (Annertz, personal communication).

Like many recently glaciated areas, the horst has an overburden that mainly comprises a thin layer of glacial till. Other glacial deposits include glaciofluvial sediments, current railway, and the spatial distribution of grazing/agricultural land (yellow) and forested areas (green) are shown (right)

primarily along the Sinarpsdalen Valley to the west (Ringberg 2000).

Along the slopes of the horst, wave-washed sediments are present. However, areas at a higher elevation were not subjected to marine transgressions following the most recent glaciation (Ringberg 2000). According to the National Atlas of Sweden (1994), the most extensive (marine) transgression following the most recent glaciation period submerged areas below 50-60 m above sea level in the vicinity of Hallandsås. Wetlands consisting of fens and bogs are present in hollows that act as local groundwater discharge areas and these are common in elevated areas of the Ridge. Hollows are commonly located above fracture zones since the fractured areas exhibit less resistance to superficial weathering than the surrounding bedrock.

The bedrock of the study area is geologically heterogeneous, consisting mainly of gneiss, with several small fault zones, amphibolite dykes (not shown) and dolerite dykes, as shown in Fig. 2. In some parts, water-bearing structures provide relatively high hydraulic conductivity.

The study area has a hydrogeological boundary towards the south marked by a wide and highly weathered weakness zone running along the southern slopes of the Ridge, followed by a $150 \mathrm{~m}$ wide amphibolite dyke. To the north, a dolerite dyke forms the hydraulic boundary. Another dolerite dyke cuts through the study area and divides it hydrogeologically into two more or less separate aquifers: the Skeadal-Flintalycke aquifer (to the south) and the Flintalycke Norr aquifer (to the north), see Fig. 2. 

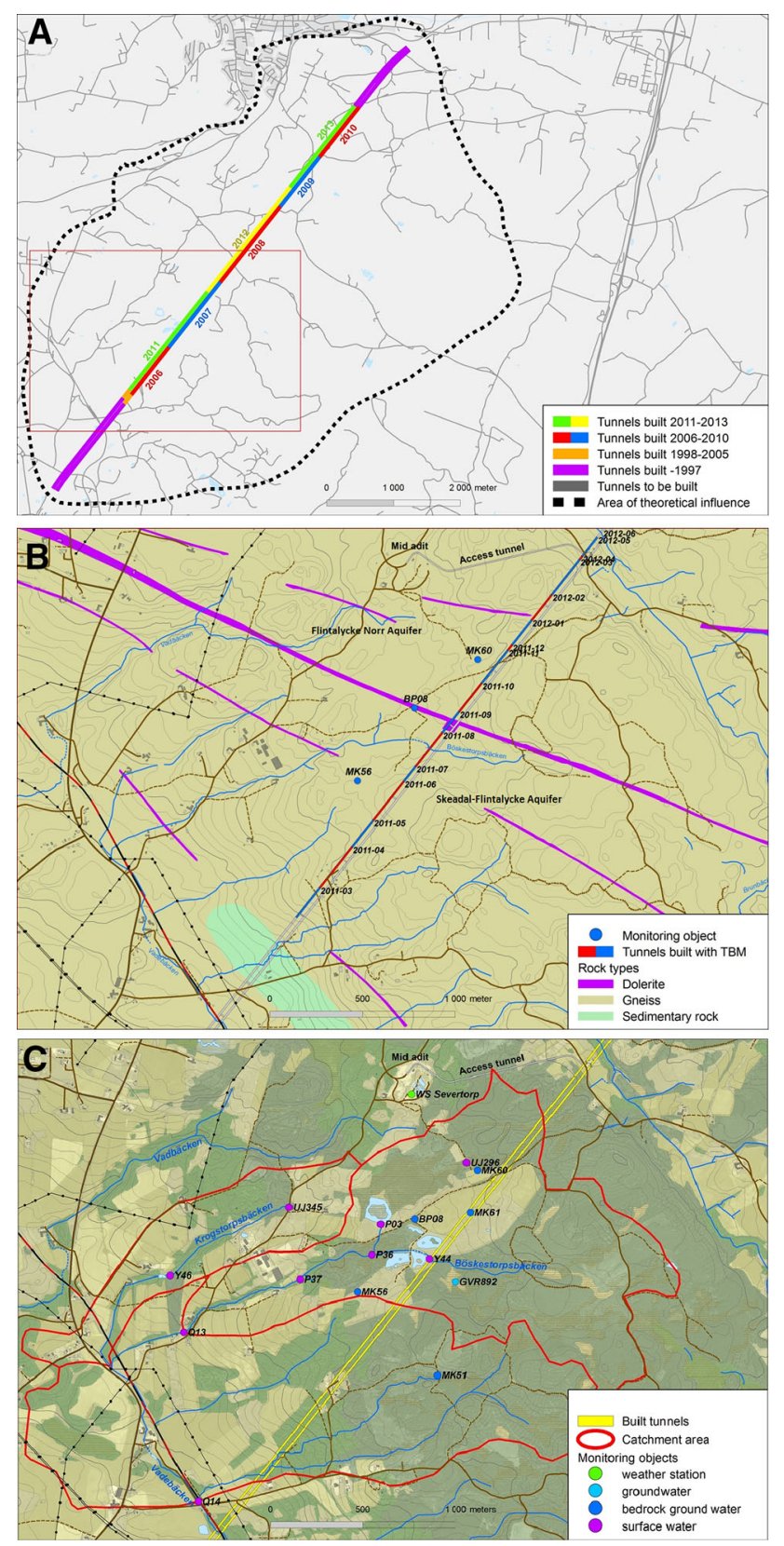

Fig. 2 a Tunnel construction sequence. The northern and southern adits were initiated during the 1990 s, mainly using the drilling and blasting method. Construction of the eastern tunnel using TBM technology took place from 2005 to 2010 . Construction of the western tunnel using TBM technology commenced in 2011. b The bedrock of the Hallandsås horst is dominated by granitic gneiss intruded by dolerite dykes. Amphibolite intrusions are present. On the southern and northern flanks of the horst, more recent sedimentary rocks overlie the igneous bedrock (Annertz 2009). c Topographical and land-use map of the study area. The boundary of the watershed is marked by a red line. Forest areas are marked in dark green and open land areas covered with vegetation, such as pasture land, are marked in light green

Both aquifers consist mainly of relatively competent rock with moderate hydraulic conductivity. Some areas of open fractures and zones of contact between the gneiss and minor dolerite entities comprise water-bearing structures. The dolerite that separates the two aquifers is almost impermeable at tunnel level and acts as a negative hydraulic boundary. Closer to the surface, however, the dolerite is more fractured, permitting some contact between the aquifers. The contact zones between the dolerite dyke and the gneiss form a water-bearing zone that is located mainly within the gneiss. All hydraulic boundaries are negative, non-flow boundaries. The hydrogeological conditions and the tunnelling activities define the area of influence. The different waterproofing methods also had an impact on the area of influence. The parts of the tunnels that had not been lined, and thus allowed for larger seepage volumes, caused persistent lowering of the groundwater levels along the northernmost and southernmost sections, see Fig. 2.

The geological conditions at the surface are shown on the quaternary geology map in Fig. 3. The overburden in the study area is dominated by fairly thin layers of glacial till, and some areas have been mapped as bedrock outcrops. In the topographically lower part of the study area, around the ponds, there is permeable soil comprising bogs and peat (Fig. 3). Hydraulically, these areas were noted to be well connected to the rock aquifer. In unaffected conditions, the water level of the rock groundwater is higher than that of the aquifer in the bogs and peat, thus posing as groundwater discharge areas.

\section{Hydrological and hydrogeological conditions}

Precipitation and temperature have been monitored at a number of stations since the project was initiated. One of the stations is located at Severtorp, near the area monitored for hydrological and hydrochemical changes in this study.

From 2000 to 2012, annual precipitation at Severtorp varied between $763 \mathrm{~mm}$ (2001) and $1122 \mathrm{~mm}$ (2007) with an arithmetic average of $872 \mathrm{~mm}$. In 2011 and 2012, total annual precipitation was 863 and $868 \mathrm{~mm}$, respectively, close to the average for the period 2000-2012. The first months of 2011 had less than normal precipitation, as can be seen in Fig. 4. From January to April 2011, $102 \mathrm{~mm}$ of precipitation were measured compared to the January-April average of $180 \mathrm{~mm}$ for the period 2000-2012. However, there was higher than usual precipitation from July to September 2011, $419 \mathrm{~mm}$, compared to the average of $311 \mathrm{~mm}$ (2000-2012). Temperatures were close to normal for most of the 2-year monitoring period compared to the calculated monthly averages for 2000-2010, as presented in Mossmark (2010). Snow depth was not measured.

Because of the geological history, the rock mass of Hallandsås is generally more fractured than the average igneous rock in Scandinavia. The fractures comprise waterbearing structures. The high presence of fractures results in 


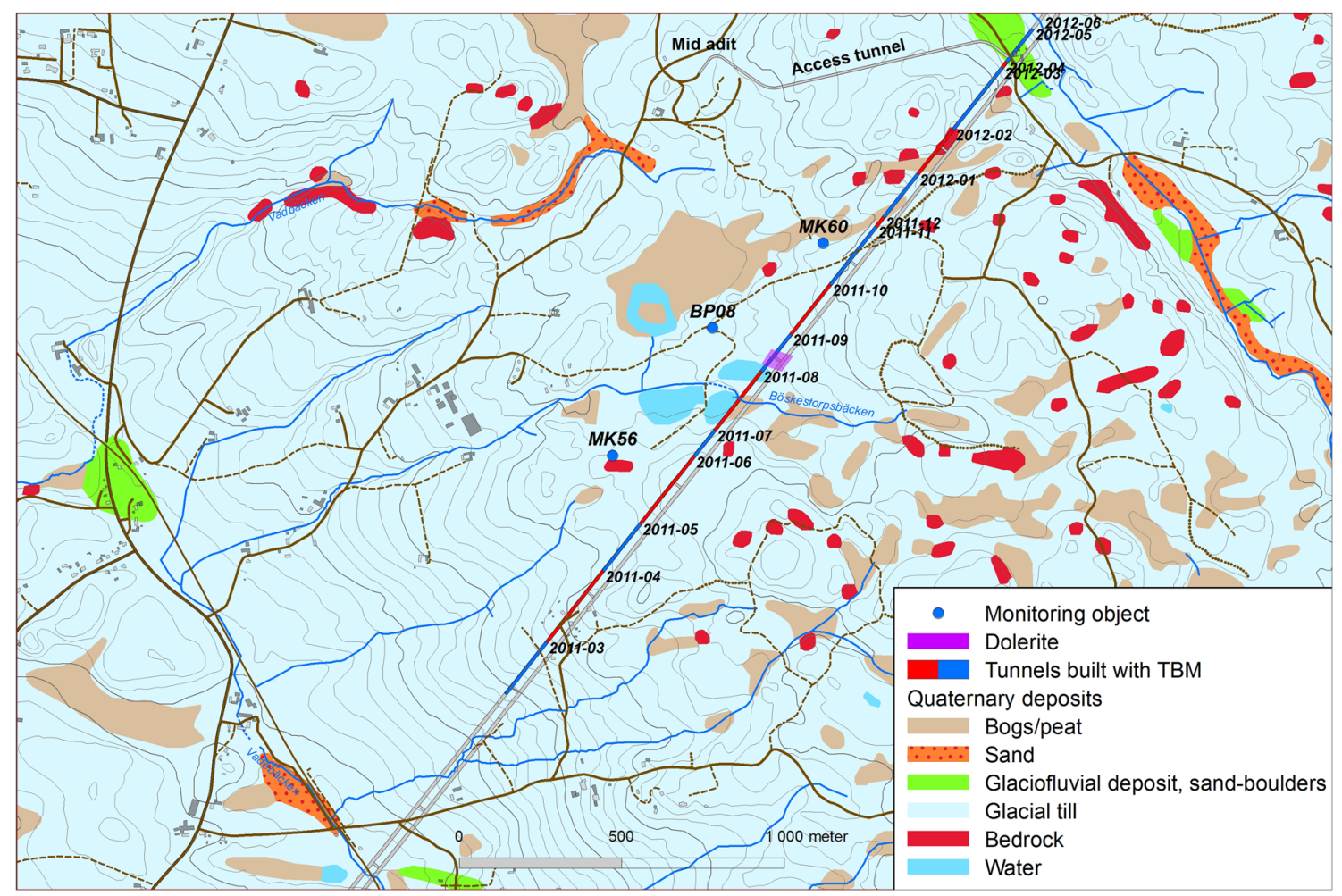

Fig. 3 Quaternary geological conditions of the study area. At the surface, the overburden is dominated by either glacial till or bogs/peat. The chronology of the construction of the western tunnel is shown to the right of the tunnel. Peat/bogs and surface water represent groundwater discharge areas, glacial till, and bedrock outcroppings represent groundwater recharge areas
Fig. 4 Average monthly temperatures and total precipitation in the study area during the period 2011-2012

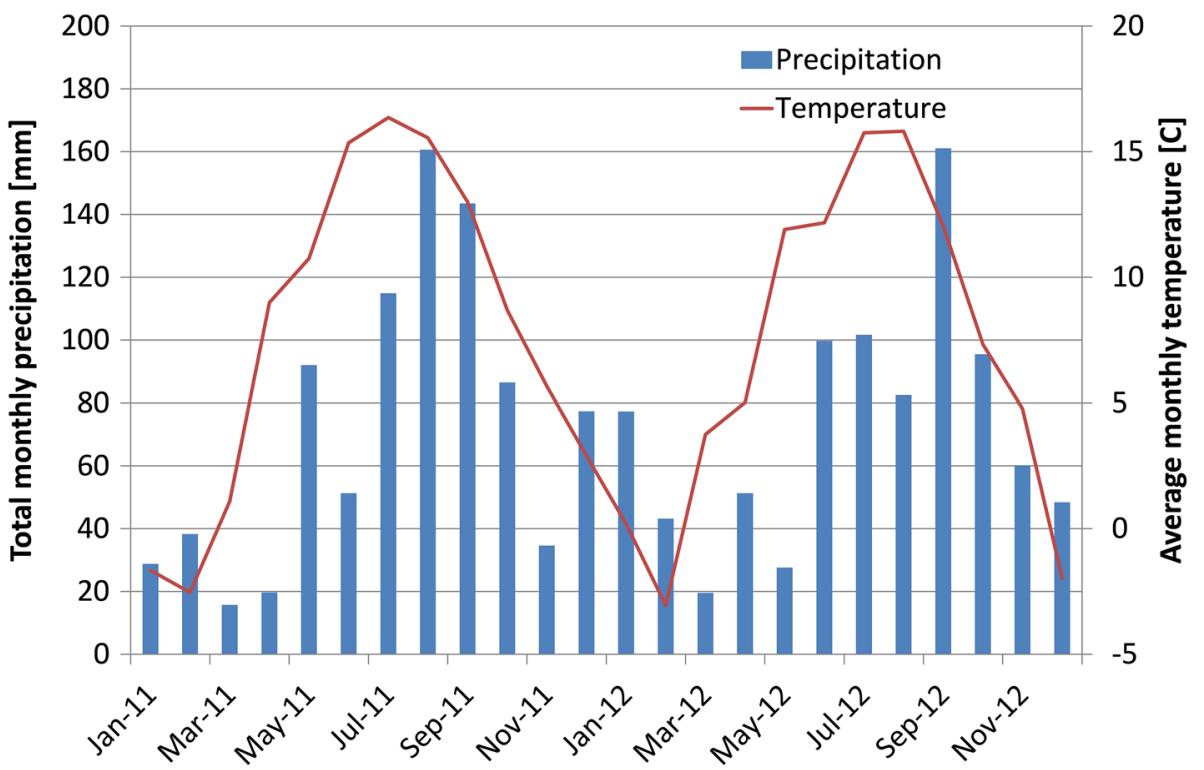

higher storativity compared to normal Scandinavian conditions (Annertz, personal communication).

The study area covers approximately two square kilometres of pasture land (Fig. 2), wetlands and forest on top of the tunnel. The area is part of the Vadebäcken catchment area and is dewatered by two small streams flowing in a southwesterly direction: Böskestorpsbäcken and, to some extent, Krogstorpsbäcken. The area is made up of two enclosed pastures divided in a northeast/southwest direction. Two small streams, one from each pasture, meet at a point south of the dividing enclosure to form a larger stream-Böskestorpsbäcken. 
Part of the northern pasture land is covered by a continuous bog, watered by small, scattered bogs outside cattle enclosures (UJ296, MK60). In the low-lying part of the study area, a ring-shaped pond has been constructed, separating the bog from the higher, drier pasture to the southwest, where the Krogstorpsbäcken stream originates from a spring (UJ345, Y46). Another stream runs from the ring-shaped pond (P03) towards the south, exiting the pasture via a covered drain leading to the confluence with the stream from the southern pasture, finally forming Böskestorpsbäcken (P36). The locations of the streams, the watershed boundary, the monitoring objects and the topography of the study area are shown in Fig. 2.

Most of the southern pasture is relatively dry with the absence of surface water. The northeastern part, however, is connected to a vast wetland (mainly marsh, with or without tree vegetation) extending towards the border of the calculated influence area of the tunnel. A small stream has its source here, near the sampling location Y44. Further down in the catchment area, the stream enters a covered drain that passes four ponds in a flat area close to one of the monitored, deep-drilled boreholes in the bedrock (BP08). In the southwest, the ground slopes from a hill (MK56) into a marshy wood where the stream exits the pasture and meets the stream from the north (P36) to form Böskestorpsbäcken (P37).

\section{Tunnel construction and time line}

The rail tunnel through the Hallandsås Ridge comprises two tunnels, each $8.6 \mathrm{~km}$ long and built mainly using a tunnel-boring machine (TBM). The tunnels will be connected by a set of cross-passages, built using the drilling and blasting method. These passages will act as emergency exits and be used for technical purposes. The elevation of the tunnel varies from $14 \mathrm{~m}$ a.s.l. at the northern adit to $27 \mathrm{~m}$ a.s.l. in its southern parts. Tunnel construction began in 1992 from the northern side of the Hallandsås Ridge. A tunnel-boring machine (TBM) was used during the initial phase. However, the TBM was soon found to be unsuitable for constructing a tunnel through the superficially weathered northern slopes of the Ridge. The construction method was subsequently changed to regular drilling and blasting. Construction came to a halt in 1997 following the occurrence of two groundwater-related obstacles.

Construction resumed in 2005 with the use of a TBM that had better capabilities for construction in fractured rock compared to the TBM used in the initial phase in 1992. The contractor used a customised tunnel-boring machine (TBM), designed to handle the complex geological conditions of the Hallandsås Ridge. The TBM was equipped with a 10.6 m-diameter cutter head. After mucking for a few metres, the TBM lined the section of the tunnel that had been created by mounting a ring of pre-cast concrete segments to form a water seal. The TBM allowed for operation in a variable pressure mode that enabled adjustment and decreased the influx of water. The cycle time for the construction procedure varied significantly depending on geological and hydrogeological conditions, ranging from a few hours to three months. Using just one TBM, construction during this phase only took place at one location at a time, working northwards from the south side of the Hallandsås Ridge (Swedish Rail Administration 2010). Tunnelling with the TBM ended with the successful breakthrough of the western tunnel in September 2013. The chronological completion of the different parts of the tunnel is presented in Fig. 2.

\section{Monitoring and instrumentation}

A large number of transducers have been installed by the Swedish Transport Administration to measure groundwater levels in boreholes in the bedrock of the Hallandsås Ridge. For most points, Schlumberger Divers have been used in combination with Geawelltech Checkpoint communication systems. Levels were also measured manually using water level tapes. These measurements were made at monthly intervals, primarily to monitor the function of the transducers (Björkman, personal communication).

The Swedish Transport Administration has presented a monitoring programme for both the hydrological conditions and the hydrochemistry during the construction phase. The collected data has been stored in a database. The extent of monitoring varied depending on the assessed impact of the tunnelling (Swedish Rail Administration 2008).

The monitoring programme for the entire tunnelling project required 12 deep-drilled boreholes in the vicinity of the tunnels to be monitored as well as one reference borehole. The general sampling frequency was twice a year. Within the framework of the study presented in this paper, the sampling frequency of the three boreholes in a selected monitoring area along the tunnels was increased to twice monthly during the period April 2011-December 2011. During spring 2012, sampling of bedrock groundwater took place each month. Details of the three boreholes are set out in Table 1.

The sampling frequency for surface water was increased from once to twice per month. In addition, one shallow filter well in the overburden was sampled on two occasions. On the third occasion, the filter well was dry and the sampling series was discontinued.

The bedrock groundwater was sampled using a submersible pump. Purging of five borehole volumes was 
Table 1 Geological observation and installation details for the three monitored boreholes

\begin{tabular}{|c|c|c|}
\hline MK56 & BP08 & MK60 \\
\hline $\begin{array}{l}\text { Percussion-drilled. Total depth } \\
123 \mathrm{~m} \\
\text { Top of casing: } 161.5 \mathrm{~m} \text { a.s.1. } \\
\text { Location: At tunnel length } 814 \mathrm{~m} \\
\perp \text { Distance from tunnel: } 190 \mathrm{~m} \\
\text { Strike/dip: Vertical } \\
\text { Overburden: Till, } 7 \mathrm{~m}(12 \mathrm{~m} \\
\text { grouted casing) } \\
\text { Rock type: } 123 \mathrm{~m} \text { gneiss } \\
\text { Fracture minerals: In gneiss, at a } \\
\text { distance from basic intrusions, } \\
\text { commonly clay and calcite }\end{array}$ & $\begin{array}{l}\text { Partly core-drilled, partly percussion-drilled. } \\
\text { Total depth } 138 \mathrm{~m} \\
\text { Top of casing: } 160.7 \mathrm{~m} \text { a.s.1. } \\
\text { Location: At tunnel length } 1311 \mathrm{~m} \\
\perp \text { Distance from tunnel: } 190 \mathrm{~m} \\
\text { Strike/dip: } 35 / 80 \\
\text { Overburden: Till, } 4 \mathrm{~m} \text { ( } 7 \mathrm{~m} \text { grouted casing). } \\
\text { Rock type: } 90 \mathrm{~m} \text { dolerite, followed by interspersed } \\
\text { gneiss and amphibolite, gneiss dominating the } \\
\text { deeper parts of the borehole } \\
\text { Fracture minerals: In gneiss, at a distance from basic } \\
\text { intrusions, commonly clay and calcite. In dolerite } \\
\text { and gneiss, chlorite and calcite commonly close to } \\
\text { it }\end{array}$ & $\begin{array}{l}\text { Percussion-drilled. Total depth } 160 \mathrm{~m} \\
\text { Top of casing: } 167.9 \mathrm{~m} \text { a.s.1. } \\
\text { Location: At tunnel length } 1,729 \mathrm{~m} \\
\perp \text { Distance from tunnel: } 140 \mathrm{~m} \\
\text { Strike/dip: Vertical } \\
\text { Overburden: Till and heavily fractured rock } \\
\text { (alternating gneiss and amphibolite) covered by } \\
42 \mathrm{~m} \text { of grouted casing } \\
\text { Rock type: Alternating gneiss/(garnet) amphibolite } \\
\text { continues up to the full depth of } 160 \mathrm{~m} \\
\text { Fracture minerals: Commonly chlorite, often in thick } \\
\text { layers, and calcite. Relatively large amounts of } \\
\text { pyrite were encountered in adjacent wells and in } \\
\text { the eastern tunnel }\end{array}$ \\
\hline
\end{tabular}

carried out in order to collect samples, which were representative of the entire length of the open borehole (packers were not used). The pump was installed at either $95 \mathrm{~m}$ (for MK56 and MK60) or $39 \mathrm{~m}$ (for BP08) depth below the top of the casing. Measurements of $\mathrm{pH}$, temperature, dissolved $\mathrm{O}_{2}$ and electrical conductivity, as well as the groundwater level were continuously made in situ during the purging and sampling activities. To carefully purge the groundwater, the pump was controlled with variable speed drive with the purpose to limit drawdown to less than $20 \%$ of the pressure at the pump level. Samples were collected in plastic bottles and kept refrigerated before being delivered to the laboratory for further appropriate handling on the day of sampling.

The hydrochemistry of the groundwater in the bedrock was also monitored within the framework of this study by means of iterated borehole logging. The device used for the logging included a Troll 9500 Water Quality Instrument equipped with sensors for pressure, temperature, $\mathrm{pH}$, electrical conductivity, oxygen, Eh (ORP), and chloride. To obtain stability during field measurements a silver-silver chloride electrode was used for the ORP measurements. During the logging, the instrument measured and registered the values for the parameters at two-second intervals. The logging was carried out by cautiously lowering the probe manually to the bottom of each borehole. Measurements were made on five occasions during the period April-December 2011.

The runoff volumes in the streams were measured manually at weirs every fortnight. Although the volume could be estimated from these measurements, in this study they are used mainly as field observations to identify hydrological changes.

\section{Results and discussion}

\section{Hydrological impact of construction in the study area}

The impact of construction of the Hallandsås tunnels on groundwater levels in the bedrock followed a general pattern. The groundwater level in a borehole would decrease as the TBM head approached, starting as constructioncreated hydraulic contact with water-bearing fractures connected to the borehole. Provided the tunnel was sealed successfully with the concrete lining, the level would start to recover once the TBM had passed. In fractured rock volumes with high hydraulic conductivity and effective contact with the tunnel through water-bearing fractures, the area of influence was larger compared to more competent rock volumes. The geological conditions varied significantly through the study area, as mentioned in the geological description section.

The drawdown and recovery processes were also affected by the variation in production methods. Groundwater levels were affected by construction through (negative) hydraulic boundaries that separate the different aquifers. Because of the absence of confining soil layers, there is obvious interaction between rock and soil on the Hallandsås Ridge. Some groundwater discharge areas, where permeable soils are well connected to the rock aquifer, became temporary groundwater recharge areas. Such conditions were observed within parts of the study area.

Figure 5 shows the fluctuation of the groundwater levels in the monitored boreholes. The groundwater levels in the three boreholes were affected significantly by tunnelling 
Fig. 5 Groundwater levels in three monitored boreholes in the bedrock within the study area. One of the boreholes (MK56) is located to the south of a dolerite dyke, one intersects the dyke (BP08, see Fig. 2) and one is located to the north of the dyke (MK60). Construction activities and related hydrogeological impact is presented in notations in the figure

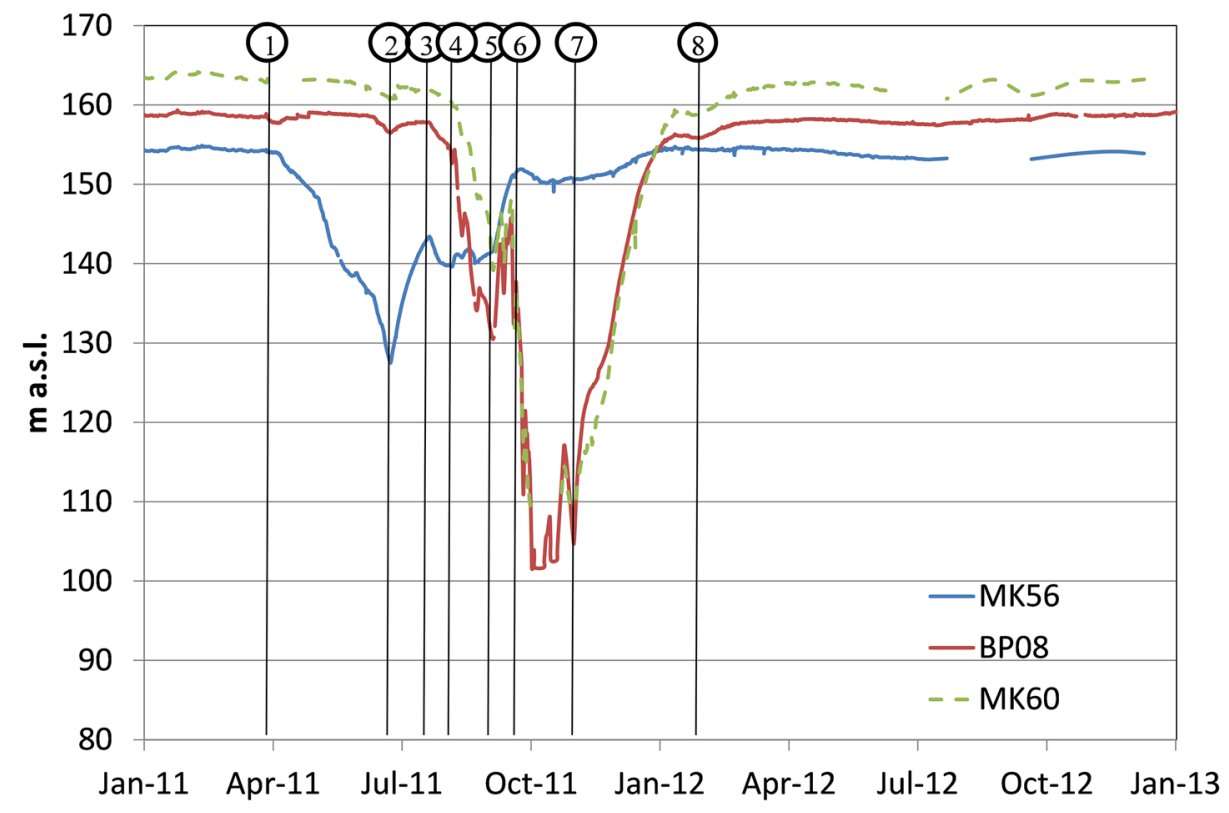

\begin{tabular}{|l|l|l|}
\hline Event & Construction activity/observation & Hydrogeological impact \\
\hline 1 & $\begin{array}{l}\text { Tunnelling through the southern hydraulic } \\
\text { boundary, which comprises competent gneiss. }\end{array}$ & Falling groundwater levels in MK56. \\
\hline 2 & $\begin{array}{l}\text { Maintenance stoppage, construction of } \\
\text { backfilling barrier. }\end{array}$ & Recovering groundwater levels in all boreholes. \\
\hline 3 & Resumption of tunnelling. & Falling groundwater levels in all boreholes. \\
\hline 4 & $\begin{array}{l}\text { Tunnelling through the hydraulic boundary, } \\
\text { which comprises a dolorite dyke located in the } \\
\text { centre of the study area. }\end{array}$ & Falling groundwater levels in MK60 and BP08. \\
\hline 5 & $\begin{array}{l}\text { Construction of a backfilling barrier. } \\
\text { Probe drilling and subsequent tunnelling north } \\
\text { of the hydraulic boundary. }\end{array}$ & $\begin{array}{l}\text { Groundwater levels recover in all monitored } \\
\text { boreholes. }\end{array}$ \\
\hline 7 & $\begin{array}{l}\text { Significantly falling groundwater levels in MK60 } \\
\text { and BP08, minor decrease in levels in MK56. }\end{array}$ \\
\hline 8 & $\begin{array}{l}\text { Tunnelling through competent gneiss north of } \\
\text { the monitored boreholes. }\end{array}$ & $\begin{array}{l}\text { Recovering groundwater levels, primarily in } \\
\text { MK60 and BP08. Gradual recovery until almost } \\
\text { unaffected levels in MK56. }\end{array}$ \\
\hline
\end{tabular}

activities, which are described in the notations for Fig. 5. The TBM commenced construction of the western tunnel from the south and the description presents events in chronological order. At event (1) the TBM entered the southern aquifer, where the rock comprised relatively competent gneiss. The most southerly of the monitored boreholes, MK56, is located in this area. There was also minor yet noticeable impact on the levels in the northern aquifer, observable through lowering of the groundwater levels in BP08 and MK60. Event (2) represents the impact of closing the TBM for a maintenance stoppage. At (3) the tunnelling recommenced and the TBM was opened, allowing influx of groundwater and thus lowering the groundwater level. On the surface, the southern pasture was affected simultaneously, particularly the ponds and the wetlands. The artesian discharge of water by the ponds ceased and the water levels in the ponds fell.

During events (4) and (5), the TBM entered the negative hydraulic boundary, comprising a $55 \mathrm{~m}$ dolerite dyke that cuts through the study area. A backfilling barrier was built to decrease the influx of water and this also led to a recovery in groundwater levels. At event (6), probe drillings yielded water, which caused a quick drawdown in the northern aquifer (BP08 and MK60). The southern aquifer (MK56), remained unaffected. The barrier prevented flow between the lining segment in the tunnel and the bedrock comprising the dolerite dyke. After tunnelling more than $250 \mathrm{~m}$ north of the dolerite dyke, a new backfilling barrier was built. The barrier once again decreased the water influx and hence led to recovery of the groundwater levels in the 
northern aquifer, see event (7). Further north, the tunnel was constructed through competent gneiss with amphibolite intrusions. The rock had few water-bearing fractures and the groundwater levels recovered further, see event (8).

The construction of cross-passages between the eastern tunnel and the western tunnel was carried out later in 2012 and had a minor impact on the groundwater levels. The impact of these activities is not discussed further in this paper. In October 2012, groundwater levels in both aquifers were still below the pre-construction levels, with gradual recovery.

\section{Hydrochemistry of surface water and shallow groundwater}

Two tributaries of the Vadebäcken watershed were studied: a northern tributary (Krogstorpsbäcken) and a southern tributary (Böskestorpsbäcken). The southern tributary (Böskestorpsbäcken) is in turn made up of two minor confluent tributaries, originating in two separate areas of wetland, as shown in Fig. 2.

Physical changes were observed due to the shallow systems drying up locally. In the study area, the main wetland was also affected during the construction periods. Construction of the eastern tunnel had previously caused the surface level of the sphagnum peat wetland to subside and springs along the streams of the Vadebäcken watershed to dry up (Björkman, personal communication). Similar hydrological changes were observed during construction of the western tunnel in 2011/2012.

Construction affected the hydrochemistry at most sampling points in the study area. The most common changes were caused by the temporary disappearance of base flow in the stream (groundwater discharge) during construction of the tunnels in the vicinity of the study area. For some of the sampling points, there was also influence from the chemical oxidation of wetlands, where noticeable results included $\mathrm{SO}_{4}$ surges and a temporary decrease in $\mathrm{pH}$. A summary of hydrochemical data for runoff water for the period 2010-2013 is presented in Table 2.

At sampling location P03 (Fig. 2), located directly downstream from a wetland, hydrochemical changes were observed during the construction of the western tunnel. The changes in the surface water chemistry at this location included the almost total disappearance of alkalinity, high $\mathrm{SO}_{4}$ concentrations and decreasing $\mathrm{pH}$, as shown in Fig. 6 . During normal seasonal variations, the hydrochemical changes are less significant. Hydrochemical recovery was observed during the summer of 2012. When the groundwater levels recovered and discharge water reappeared in early 2011, an increase in $\mathrm{SO}_{4}$ concentrations and a simultaneous decrease in $\mathrm{pH}$ and low alkalinity were observed.
At Y44 (Fig. 2), the easternmost sampling point in the southern tributary, alkalinity was non-existent during construction of the eastern tunnel in 2007 (Mossmark et al. 2010). During the period of recovered groundwater levels (2008-2011), alkalinity was once again present. The disappearance of alkalinity was reiterated during construction of the western tunnel (2011/2012), as shown in Fig. 7. Furthermore, $\mathrm{SO}_{4}$ concentrations were affected during the tunnelling periods. The most likely reasons for these changes were the varying presence of base flow (groundwater discharge) in the stream and oxidation of a wetland located upstream from Y44. In early 2012, the groundwater levels recovered and the base flow became evident, with the reappearance of alkalinity and increasing $\mathrm{pH}$ (not shown) despite a simultaneous $\mathrm{SO}_{4}$ surge.

At the P36 sampling point (Fig. 2), situated downstream from the confluence of the two minor tributaries, the base flow (groundwater discharge) most probably disappeared during tunnel construction through the area. As at $\mathrm{Y} 44$, alkalinity was absent and pH decreased during the 2007 and 2011/2012 construction periods. However, the decrease in $\mathrm{pH}$ was more significant during construction of the eastern tunnel in 2007 (pH 4.0) compared to construction of the western tunnel in 2011-2012 (pH 5.5). The concentration of $\mathrm{SO}_{4}$ increased to approximately $60 \mathrm{mg} / \mathrm{L}$ during spring 2012 although a recovery with decreasing concentrations was noted the following summer and autumn. Further downstream, at the P37 sampling point, similar hydrochemical changes were evident, albeit weaker than at P36/Y44. Shallow groundwater was monitored in filter well GVR892 although samples were only collected successfully on two occasions. The hydrochemical changes in the shallow groundwater were observed to be similar to findings in the nearby streams.

At sampling point UJ345 (see Fig. 2), low pH values were measured during spring 2012. At this point, $\mathrm{SO}_{4}$ surges were also observed during recovery after the two periods of tunnel construction in 2006/2007 and 2011/2012. An $\mathrm{SO}_{4}$ surge was also observed in late 2009, which may be caused by the natural hydrological cycle. It has been noted that such surges commonly occur at the end of the dry season when water levels recover in wetlands that had previously become dry and aerated (Mossmark et al. 2008). At the Y46 sampling point, located downstream, similar changes to those found in UJ345 were observed, albeit less significant.

\section{Groundwater in the bedrock}

At Hallandsås, the three monitored boreholes revealed hydrochemical properties that had been affected by construction of the western tunnel. Under unaffected conditions, the hydrochemistry of bedrock groundwater commonly displays insignificant seasonal variations, see 
Table 2 Compilation of hydrochemical data from the monitored stations

\begin{tabular}{|c|c|c|c|c|c|c|c|c|c|}
\hline Location & $\mathrm{pH}$ & $\mathrm{HCO}_{3}^{-}$ & $\mathrm{Cl}^{-}$ & $\mathrm{SO}_{4}^{2-}$ & $\mathrm{Ca}^{2+}$ & $\mathrm{K}^{+}$ & $\mathrm{Mg}^{2+}$ & $\mathrm{Na}^{+}$ & DOC \\
\hline \multicolumn{10}{|c|}{ Runoff, Y44 } \\
\hline Mean & 6 & 8 & 12 & 14 & 7 & $<2.0$ & 2 & 2 & 20 \\
\hline $\operatorname{Max}$ & 6.9 & 36 & 15 & 43 & 16 & $<2.0$ & 4.6 & 4.6 & 45 \\
\hline Min & 5.3 & 0 & 8.4 & 2.3 & 3.1 & $<2.0$ & 1.1 & 1.1 & 7.8 \\
\hline$n$ & 47 & 47 & 47 & 47 & 47 & 47 & 47 & 47 & 19 \\
\hline \multicolumn{10}{|c|}{ Runoff, P03 } \\
\hline Mean & 7 & 30 & 11 & 51 & 25 & - & 4 & 8 & 14 \\
\hline $\operatorname{Max}$ & 7.7 & 72 & 14 & 140 & 39 & 0.9 & 5.1 & 10 & 25 \\
\hline Min & 5.5 & 0 & 6.5 & 12 & 4.7 & 0 & 1.4 & 3.9 & 7 \\
\hline$n$ & 63 & 61 & 44 & 53 & 45 & 45 & 45 & 45 & 15 \\
\hline \multicolumn{10}{|c|}{ Runoff, P36 } \\
\hline Mean & 7 & 23 & 11 & 30 & 17 & $<2.0$ & 3 & 8 & 15 \\
\hline Max & 7.6 & 48 & 15 & 190 & 55 & $<2.0$ & 14 & 11 & 29 \\
\hline Min & 5.5 & 1.8 & 8.4 & 5 & 3.2 & $<2.0$ & 1.1 & 5.8 & 4.6 \\
\hline$n$ & 38 & 33 & 37 & 38 & 37 & 33 & 37 & 37 & 17 \\
\hline \multicolumn{10}{|c|}{ Runoff, P37 } \\
\hline Mean & 7 & 31 & 12 & 7 & 18 & $<2.0$ & 3 & 9 & 9 \\
\hline Max & 7.8 & 82 & 15 & 7.8 & 29 & $<2.0$ & 4.4 & 10 & 21 \\
\hline Min & 6.1 & 3.5 & 8.8 & 6.1 & 6.7 & $<2.0$ & 1.5 & 6.4 & 2.8 \\
\hline$n$ & 37 & 37 & 37 & 37 & 37 & 37 & 37 & 37 & 22 \\
\hline \multicolumn{10}{|c|}{ Runoff, UJ345 } \\
\hline Mean & 7 & 30 & 11 & 32 & 20 & 3 & 3 & 7 & \\
\hline Max & 7.6 & 94 & 17 & 84 & 30 & 4 & 4.5 & 9.2 & \\
\hline Min & 6.4 & 6.7 & 7.6 & 16 & 10 & $<2$ & 1.9 & 5.2 & \\
\hline$n$ & 49 & 49 & 30 & 37 & 31 & 31 & 31 & 31 & \\
\hline \multicolumn{10}{|c|}{ Bedrock GW, MK56 } \\
\hline Mean & 7 & 75 & 10 & 20 & 24 & 1 & 4 & 9 & 2 \\
\hline $\operatorname{Max}$ & 7.5 & 91 & 13 & 34 & 32 & 1.5 & 5.2 & 11 & 2.7 \\
\hline Min & 6.9 & 63 & 7.9 & 6 & 19 & 1.1 & 3.3 & 6.9 & 0 \\
\hline$n$ & 42 & 42 & 42 & 42 & 43 & 19 & 43 & 43 & 15 \\
\hline \multicolumn{10}{|c|}{ Bedrock GW, MK60 } \\
\hline Mean & 7 & 60 & 14 & 44 & 25 & 1 & 6 & 11 & 2 \\
\hline $\operatorname{Max}$ & 7.4 & 72 & 19 & 150 & 47 & 1.4 & 11 & 13 & 11 \\
\hline Min & 6.1 & 39 & 11 & 15 & 18 & 0.98 & 4.4 & 9.1 & 0 \\
\hline$n$ & 40 & 40 & 40 & 40 & 40 & 12 & 40 & 40 & 17 \\
\hline \multicolumn{10}{|c|}{ Bedrock GW, BP08 } \\
\hline Mean & 7 & 78 & 11 & 87 & 44 & 2 & 9 & 11 & 3 \\
\hline $\operatorname{Max}$ & 7.6 & 97 & 15 & 240 & 82 & 2.4 & 17 & 14 & 17 \\
\hline Min & 6.3 & 47 & 9.1 & 19 & 24 & 1.1 & 4.4 & 9.6 & 1.1 \\
\hline$n$ & 35 & 35 & 35 & 35 & 35 & 13 & 35 & 35 & 14 \\
\hline
\end{tabular}

For runoff, data from 2010 to 2013 are presented, whereas for the groundwater, data from the period 2006-2013 are presented for example Mossmark et al. (2007). The changes were similar to those observed during construction of the eastern tunnel, as presented in Mossmark et al. (2010). The hydrochemical conditions and their changes differed between the boreholes due to geological conditions, with two of the boreholes exhibiting more significant changes in $\mathrm{pH}$ and major anions and cations. Data for the groundwater in the bedrock is presented separately for the northern and southern aquifers. Discussion of the results from the borehole located in the southern aquifer, MK56, are followed by discussions of the results from the boreholes in the northern aquifer, BP08, and MK60. A summary of hydrochemical data for the bedrock groundwater is presented in Table 2. 
Fig. 6 Alkalinity (as mg/L $\left.\mathrm{HCO}_{3}\right), \mathrm{pH}$, and $\mathrm{SO} 4$ concentrations at sampling point P03. 1 The stream became dry during autumn 2011 and sampling was not possible. 2 In spring 2012, the flow recovered and an acid pulse with a high $\mathrm{SO}_{4}$ concentration and diminished alkalinity occurred. 3 Hydrochemical recovery was observed during the summer of 2012

Fig. 7 Alkalinity (as $\mathrm{mg} / \mathrm{L}$ $\mathrm{HCO}_{3}$ ), $\mathrm{Ca}$, and $\mathrm{SO}_{4}$ concentrations at the $\mathrm{Y} 44$ sampling point. 1 The base flow disappeared towards the end of summer 2011, resulting in the absence of alkalinity. $2 \mathrm{SO}_{4}$ concentrations increased sharply when the base flow returned in early 2012. The increase was probably caused by oxidation of a wetland located upstream
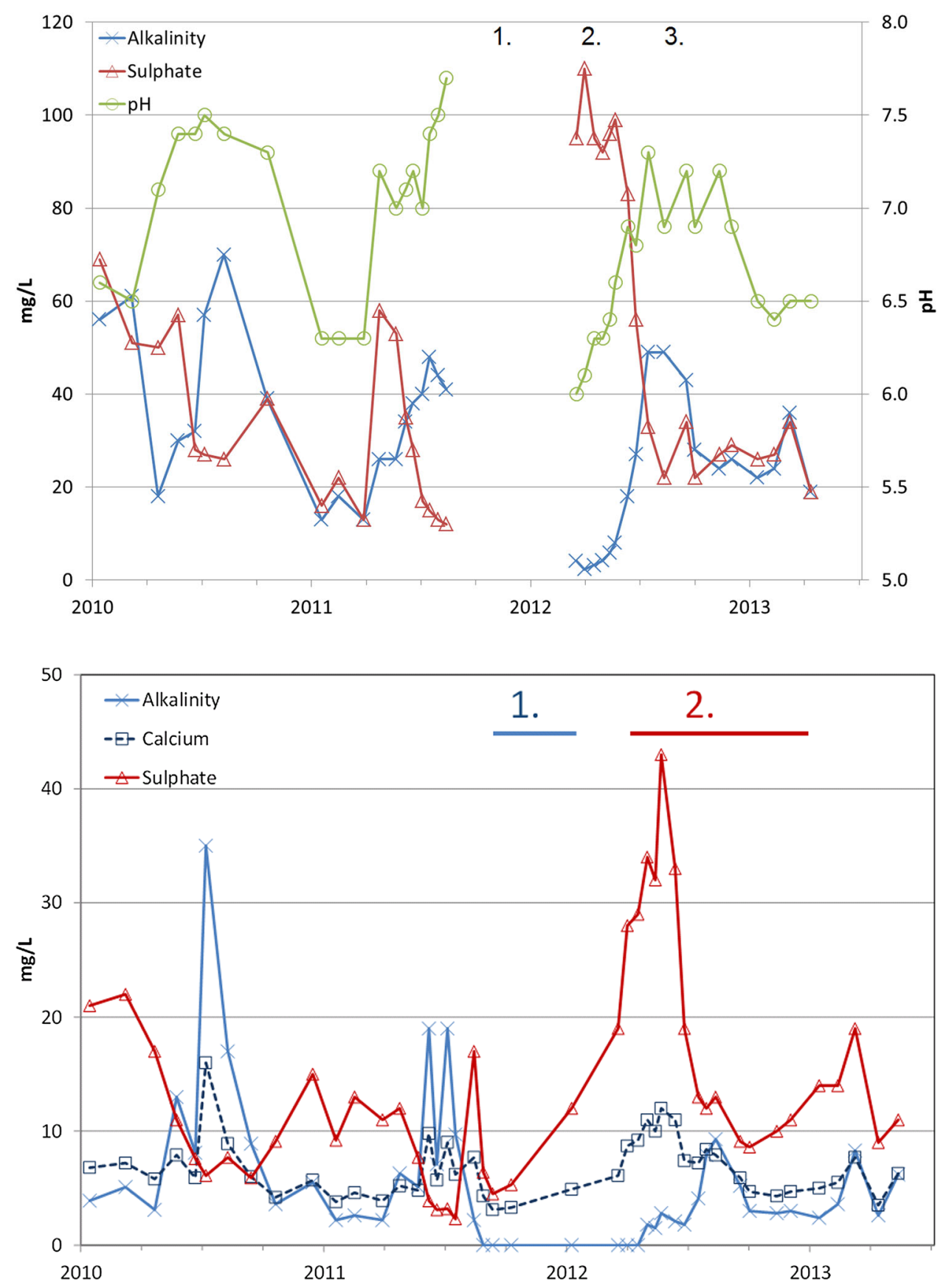

\section{Observations in borehole MK56}

The southernmost borehole, MK56 (located in the southern aquifer, Fig. 2), revealed changes in concentrations of Fe, $\mathrm{Mn}$, and $\mathrm{SO}_{4}$ during construction of the western tunnel. However, the changes were noted to be less significant during construction of the western tunnel compared to the eastern tunnel. During the period when the groundwater levels in MK56 were lowered due to tunnelling activities, the concentrations of dissolved $\mathrm{Fe}$ and $\mathrm{Mn}$ decreased (see Mossmark 2014). The concentrations of $\mathrm{SO}_{4}$ increased by approximately $50 \%$ during recovery of groundwater levels. The changes in $\mathrm{Fe}, \mathrm{Mn}$, and $\mathrm{SO}_{4}$ may have been caused by redox changes decreasing the solubility of $\mathrm{Fe}$ and $\mathrm{Mn}$, as well as oxidation of sulphides (primarily $\mathrm{FeS}_{2}$ ) in the bedrock. However, there may also have been an influx of shallow groundwater from surrounding wetlands that were subjected to oxidation, thus releasing $\mathrm{SO}_{4}$.

The borehole loggings show increasing redox potential from February to April 2011 (Fig. 8). The redox potential decreased slightly between April and July, only to increase again between July and August. A recovery could be seen 
in autumn 2011. The observed redox changes coincide with tunnelling activity in the vicinity of MK56 and are likely to have been related to the influx of water into the tunnels and subsequently the groundwater levels and recharge (Fig. 8). Measuring of the impact on groundwater levels of tunnelling with a TBM was initiated in late March 2011, and this has most probably caused an increase in redox potential through induced groundwater recharge. The redox potential recovered during periods of lower water influx (the TBM was shut down, thereby closing off the influx of water during planned maintenance) and after the TBM had excavated the tunnel through the area and the waterproofing system had been successfully installed.

The concentrations of alkalinity, $\mathrm{Ca}$, and $\mathrm{Mg}$ paralleled those of $\mathrm{SO}_{4}$ in MK56, as shown for Ca in Fig. 9. The concentrations of these parameters increased during the recovery of the groundwater levels. Such an increase could also be observed during recovery following construction of the eastern tunnel in 2007 (Mossmark et al. 2010). During construction of the western tunnel in the vicinity of MK56, pH was only affected slightly. A minor decrease in $\mathrm{pH}$ could be observed from early 2011 to mid-2012. The probable oxidation of pyrite $\left(\mathrm{FeS}_{2}\right)$ is also the likely cause of changes in $\mathrm{pH}, \mathrm{Ca}, \mathrm{Mg}$, and $\mathrm{SO}_{4}$. Oxidation of $\mathrm{FeS}_{2}$ causes the release of $\mathrm{H}$ ions and $\mathrm{SO}_{4}$, resulting in calcite/dolomite dissolution with the consequent release of $\mathrm{Ca}$ and $\mathrm{Mg}$.

In MK56, TOC was not present before construction of the eastern tunnel using a TBM in 2007. Since the study area became affected by construction work, TOC has been persistently present with a brief peak during construction of the western tunnel in 2011. The presence of TOC indicates increased groundwater recharge with organic content.
Mossmark (2010) presents conceptual models that describe probable hydrochemical changes in different quaternary geological settings. Figure 10 presents conditions similar to those present near MK56. According to Mossmark (2010), the most important hydrochemical changes that are likely to occur are related to the solubility of $\mathrm{Fe}$ and $\mathrm{Mn}$ because of changes in groundwater recharge and redox state. However, tangible changes in $\mathrm{SO}_{4}$ (and thus also in dependent parameters) were observed at MK56. The presence of a sulphur pool in a nearby wetland may be the cause. Such conditions have previously been observed, e.g. in Mossmark et al. (2015a). However, the possibility of pyrite being present in the bedrock, which could be subject to oxidation, cannot be excluded.

\section{Observations in boreholes BP08 and MK60}

Concurrent and simultaneous hydrochemical changes were observed in the other two monitored boreholes, BP08 and MK60 (located in the northern aquifer, see Fig. 2). For several parameters of concern with regard to the durability of construction materials in a tunnel (steel and cement), the changes were more significant than in MK56.

The TOC concentrations increased in BP08 and MK60 during periods of lowering of groundwater levels caused by construction of the eastern (2007) and western (2011-2012) tunnels. The measured concentrations of TOC during these events varied between 1.5 and $2.5 \mathrm{mg} / \mathrm{L}$. Before construction of the eastern tunnel in the vicinity of the study area during 2006/2007, the concentrations of TOC were below the detection limit in both boreholes $(<1.0 \mathrm{mg} / \mathrm{L})$. After the first passage of the TBM in 2007,
Fig. 8 Borehole logging in MK56. The results reveal increasing redox potential during drawdown of the groundwater level. The redox potential decreased during recovery of the groundwater levels in autumn 2011

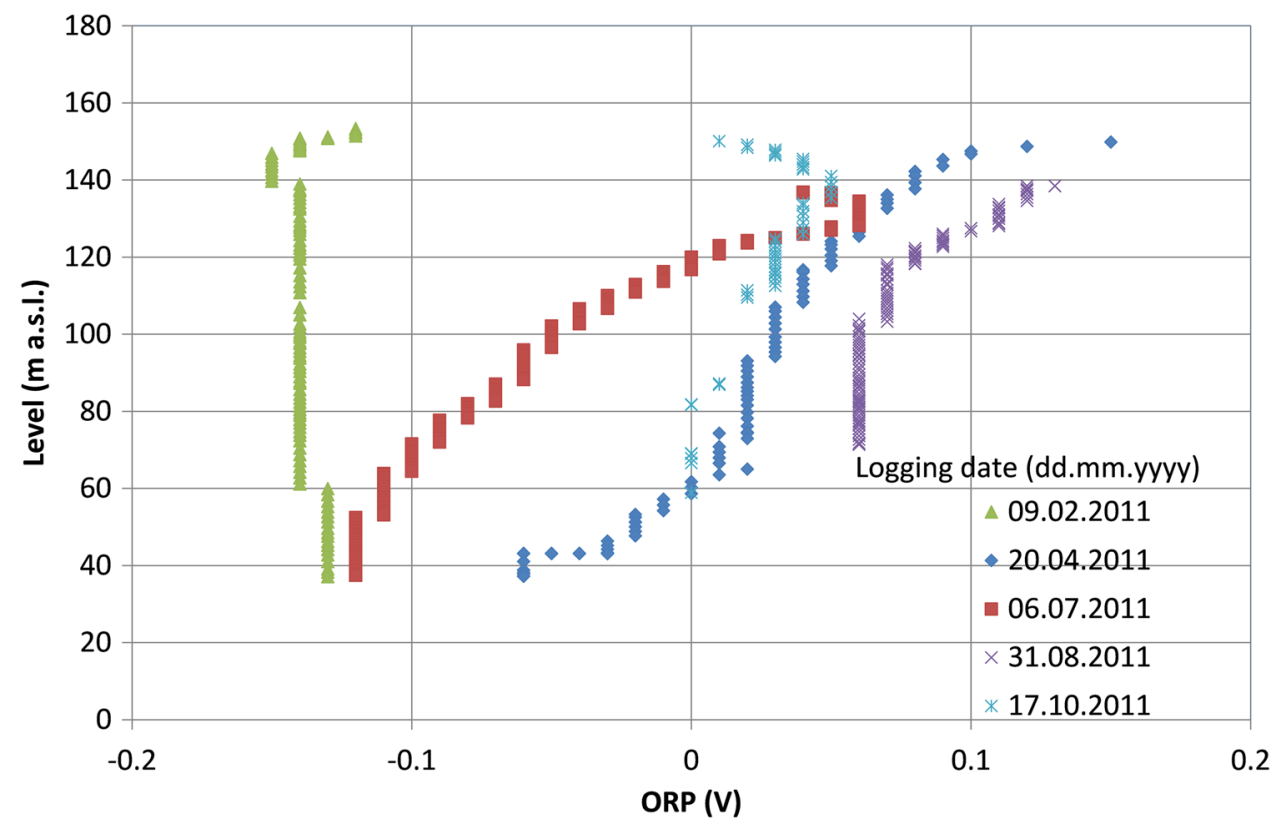


Fig. 9 Concentrations of $\mathrm{SO}_{4}$, $\mathrm{Ca}$, as well as groundwater levels in MK56. The concentrations increased during recovery of the groundwater levels after completion of the western tunnel and its waterproofing system in autumn 2011

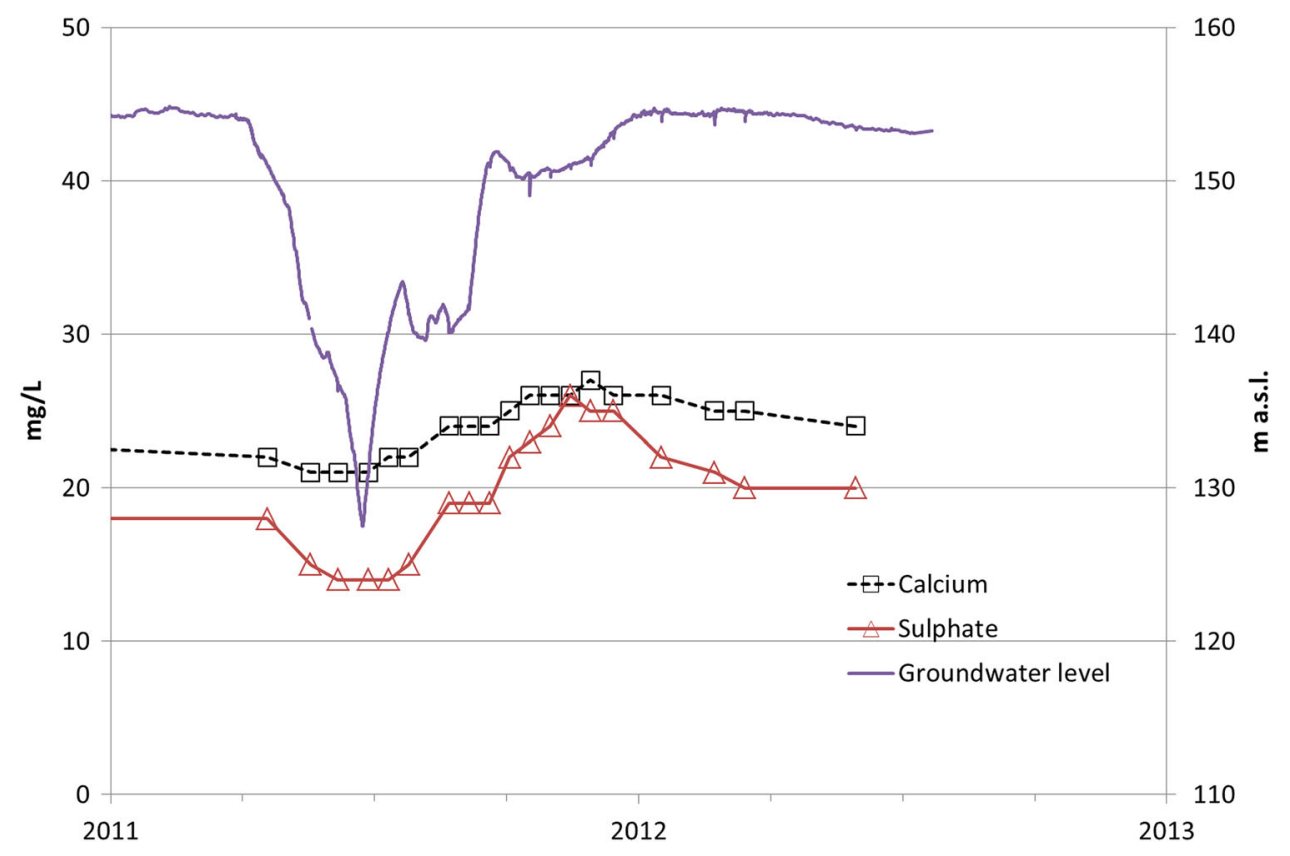

increased recharge of shallow, oxidised groundwater countered and exceeded the effect of degrading organic matter (see Fig. 11 for MK60). It is probable that the existence of partially unsaturated conditions in the bedrock groundwater, with free access to oxygen, became more common during the construction periods. Under such conditions, organic matter is generally degraded without causing a depletion of oxygen or processes that cause an increase in $\mathrm{CO}_{2}$ in the groundwater or a reduction in other dissolved elements or compounds. Figure 12 shows increasing redox potential in MK60 during construction with results similar to MK56. In addition, $\mathrm{NO}_{3}$ concentrations increased in MK60 during the period when groundwater levels recovered. This would indicate the influence of shallow waters as well as a relatively oxidised environment.

Before construction of the eastern tunnel in 2007, the $\mathrm{SO}_{4}$ concentrations in BP08 were approximately $20 \mathrm{mg} / \mathrm{L}$, as shown in Fig. 12. During the recovery of groundwater levels, the $\mathrm{SO}_{4}$ concentrations increased more than fivefold. Following recovery to more stable levels, the $\mathrm{SO}_{4}$ concentrations varied between two and three times the original concentrations (mid-2008 to mid-2011). When the groundwater levels recovered after construction of the western tunnel through the study area, concentrations increased more than tenfold compared to the original concentrations. This episode was followed by a recovery of $\mathrm{SO}_{4}$ with decreasing concentrations. Alkalinity and $\mathrm{pH}$ decreased during the episodes of high $\mathrm{SO}_{4}$. A decreasing trend for these two parameters can be seen for the entire monitoring period, i.e. 2007 to 2012. The concentrations of the base cations $\mathrm{Ca}, \mathrm{Mg}$, and $\mathrm{Na}$, as well as the concentrations of $\mathrm{Mn}$, paralleled those of $\mathrm{SO}_{4}$. 

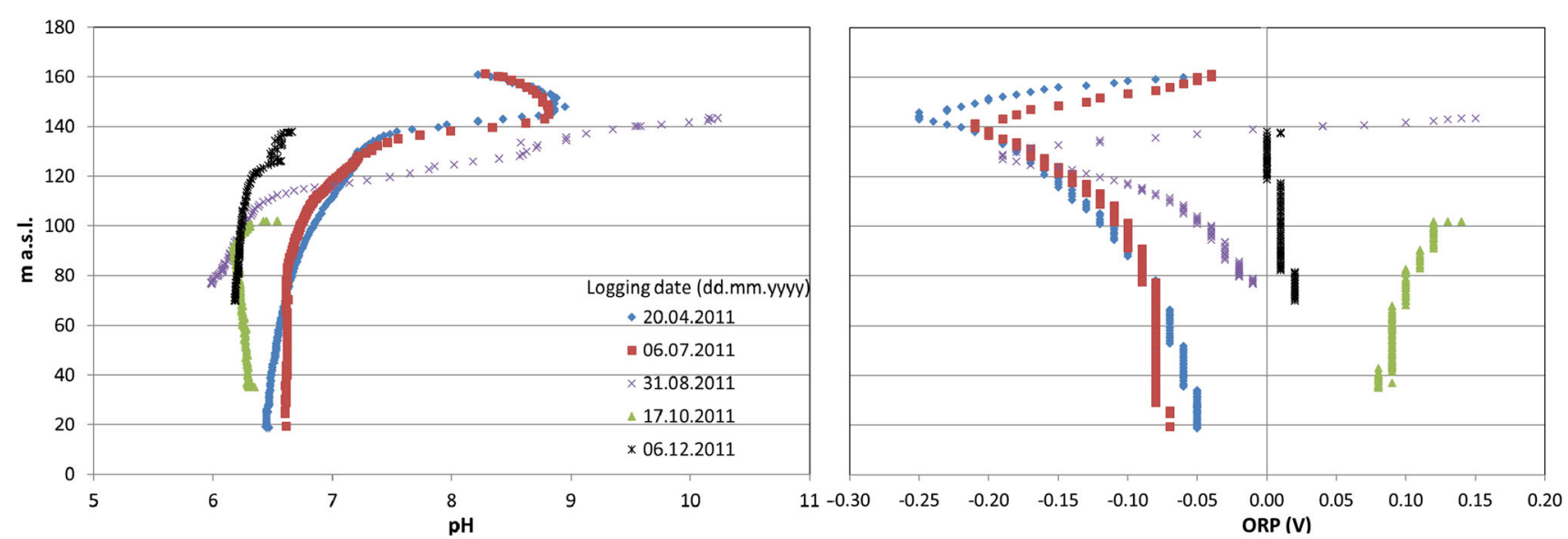

Fig. 11 Logging of $\mathrm{pH}$ (left) and redox (ORP, right) in the MK60 borehole. The $\mathrm{pH}$ decreased during construction in the vicinity of the borehole and remained low until the end of 2011. Meanwhile, the redox potential increased in MK60 during the tunnelling activities for the western tunnel through the area. Recovery, with decreasing redox potential, was observed in late 2011 in conjunction with the recovery of the groundwater levels
Fig. $12 \mathrm{SO}_{4}, \mathrm{pH}$ and groundwater level in borehole BP08 during construction of the two tunnels using a TBM. The construction of the eastern tunnel caused decreasing groundwater levels in 2007/2008, whereas the western tunnel affected groundwater levels during 2011/2012

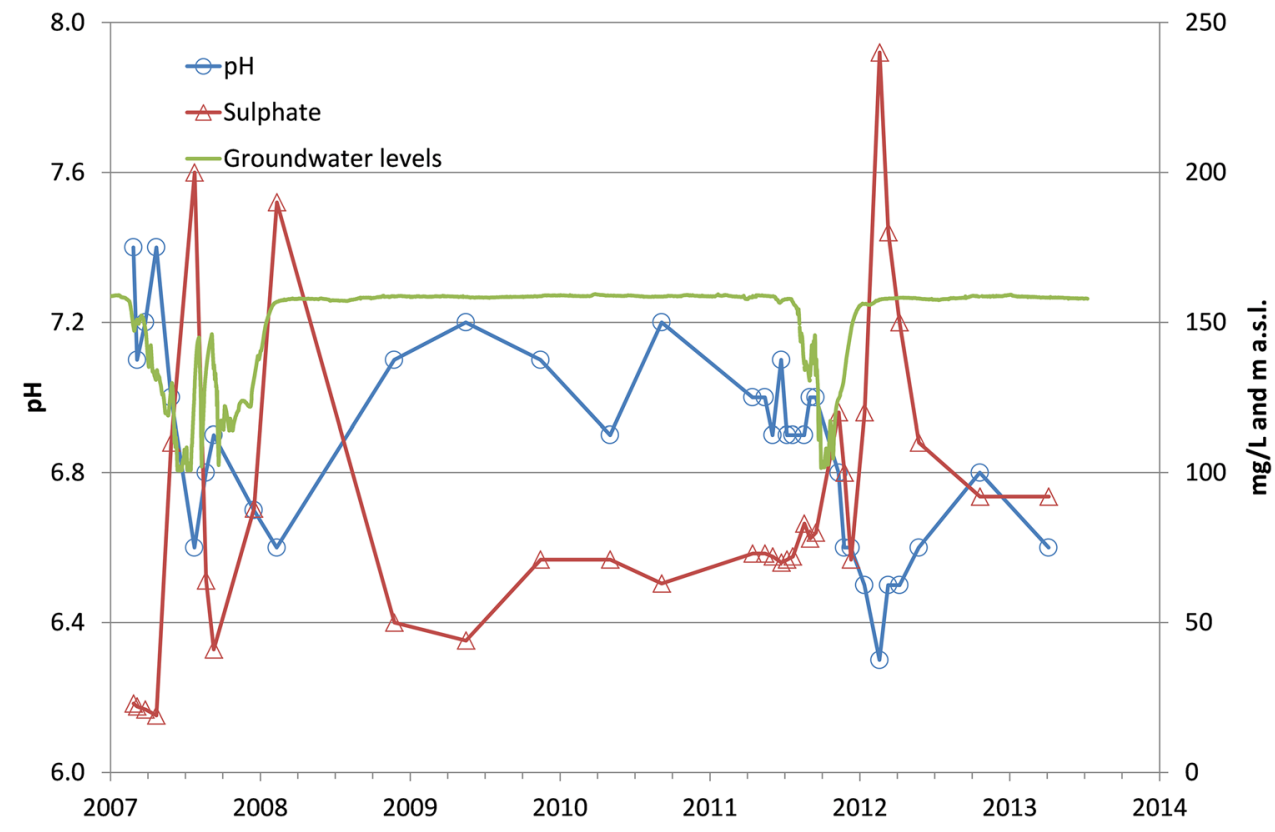

As with $\mathrm{BP} 08$, the concentrations of $\mathrm{SO}_{4}$ in $\mathrm{MK} 60$ also increased more than fivefold during the recovery of the groundwater levels following construction of the tunnels through the area. The variability is presented in Table 2. During the period with lowered groundwater levels during the tunnelling of the western tunnel near the study area, Fe concentrations in the two boreholes decreased. Similar to MK56 (see Mossmark 2014), the concentrations recovered alongside the groundwater levels.

The increased $\mathrm{SO}_{4}$ concentrations in BP08 and MK60 are most probably caused by pyrite $\left(\mathrm{FeS}_{2}\right)$ oxidation. Documentation from the drilling of the boreholes indicates the presence of pyrite in the bedrock (Sangskär, personal communication). Along with a decrease in $\mathrm{Fe}$ concentrations, this would confirm the measured increase (Fig. 11) in redox potential. The observed changes in redox are probably caused by increased groundwater recharge. The $\mathrm{Ca}$ and $\mathrm{Mg}$ concentrations, as well as $\mathrm{Mn}$ concentrations, paralleled those of $\mathrm{SO}_{4}$ in MK60. It is difficult, however, to isolate the results from processes occurring in the bedrock from those occurring in the overburden. According to Giblin and Wieder (1992) and others, sulphide minerals are abundant and available in sphagnum peat wetlands and are similar to the fracture minerals. The BP08 and MK60 boreholes are located in the proximity of the peat wetland in the study area.

The increased $\mathrm{SO}_{4}$ concentrations caused a lowering of $\mathrm{pH}$ and alkalinity. Figure 11 reveals $\mathrm{pH}$ measurements 
Fig. 13 Bar chart showing changes for major cations and anions in BP08. The most significant changes among the anions were for $\mathrm{SO}_{4}$. For the cations, the concentrations of $\mathrm{Ca}, \mathrm{Mg}$, and $\mathrm{Na}$ increased proportionally during the recovery of groundwater levels in borehole BP08 at the beginning of 2012

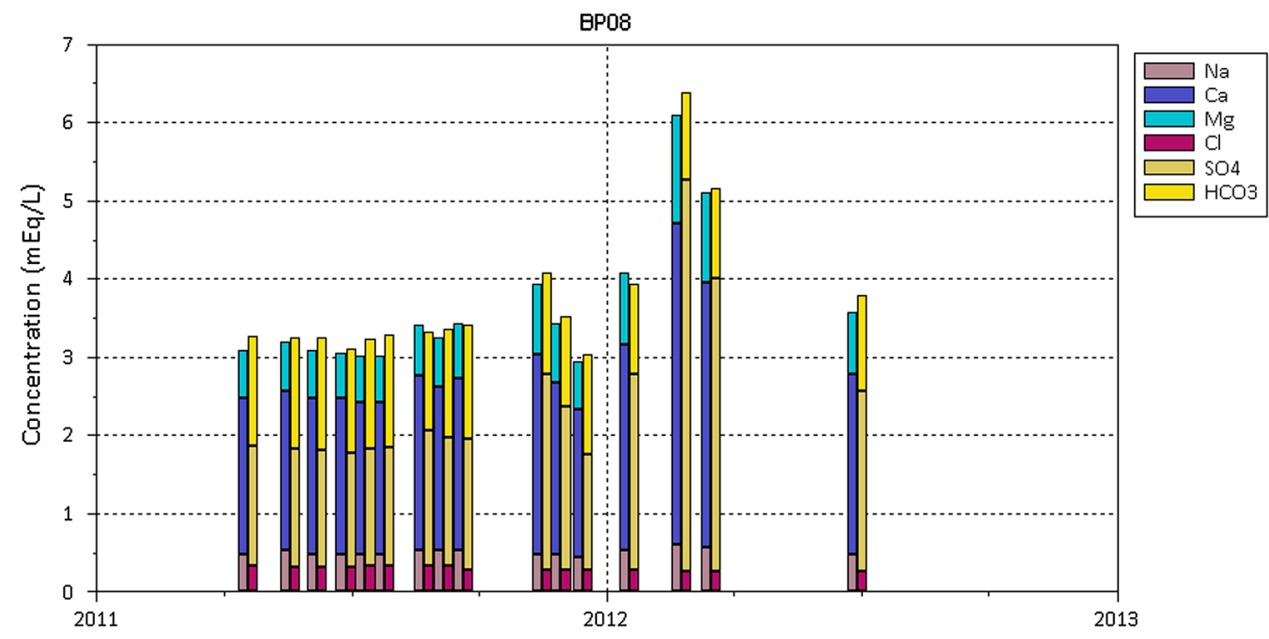

from borehole logging in MK60. The results show a general alkaline environment in the upper parts of the borehole. The two initial logging occasions revealed a $\mathrm{pH}$ of approximately 6.5 at levels below $80 \mathrm{~m}$ above sea level. As shown in Fig. 11, the three subsequent measurements revealed a lower $\mathrm{pH}$, approximately 6.0 at levels below $80 \mathrm{~m}$ above sea level.

Figure 13 shows a bar chart displaying the major anions and cations for groundwater in BP08. The concentrations of $\mathrm{SO}_{4}$ increased during recovery of the groundwater levels in early 2012. $\mathrm{SO}_{4}$ became more prevalent compared to the other major anions, $\mathrm{Cl}$ and $\mathrm{HCO}_{3}$. For the cations, $\mathrm{Ca}, \mathrm{Mg}$, and $\mathrm{Na}$, concentrations increased along with the sum of the anions. As opposed to the anions, the ratio between the cations remained fairly constant.

Mossmark (2010) presented conceptual models that linked quaternary geology to probable hydrochemical changes in conjunction with underground constructions. Figure 14 describes a model for the geological conditions that are present in the vicinity of BP08 and MK60 with groundwater discharge areas comprising wetlands. According to Mossmark (2010), the groundwater discharge areas may become groundwater recharge areas with subsequent hydrochemical changes, such as the oxidation of sulphides. However, the model excludes the impact of processes in the bedrock, such as pyrite oxidation and calcite dissolution. The results from the monitoring indicate a combination of the processes mentioned in the model and the impact of fracture minerals.

\section{Comparison of the results from the two aquifers}

The results from this study confirm that geological conditions are of significant importance to the hydrochemical changes that occur during the construction and operation of underground facilities (as found by e.g. Mossmark et al. 2008 and Mathurin et al. 2012). As shown in Fig. 5, the

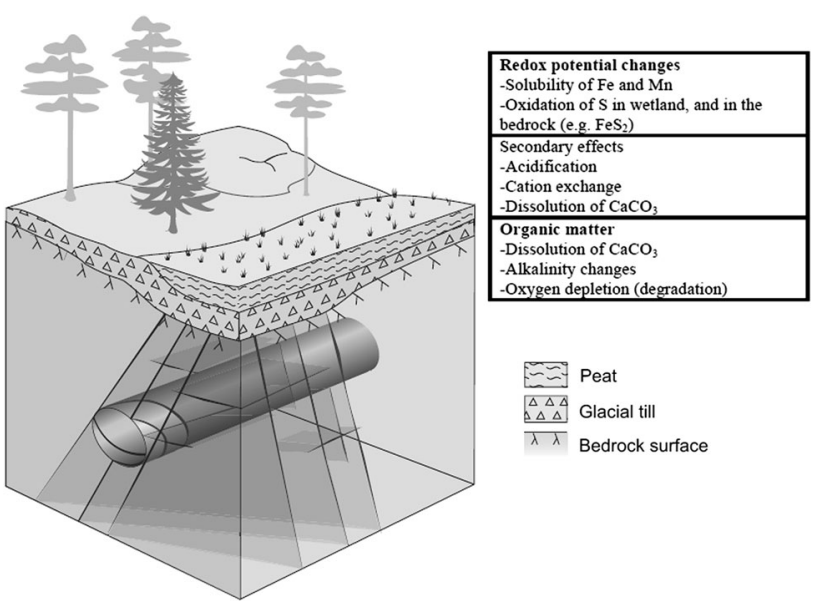

Fig. 14 A schematic, conceptual model of geological conditions for a groundwater discharge area that has not been subject to marine transgressions [Mossmark (2010), modified from Eklund (2001)]. This is the type of environment that is expected to be present near BP08 and MK60. The glacial till is overlain by peat. In the figure, a fracture zone intersects the tunnel and the wetland, similar to the conditions in BP08

drawdown was more significant in BP08 and MK60 compared to MK56. However, the more significant hydrochemical changes are not interpreted as being linked to the magnitude of the drawdown.

Borehole MK56 was drilled through relatively homogenous rock and it displayed mainly changes in redox and the solubility of Fe and Mn. BP08 intersects a contact zone between a dolerite dyke and surrounding gneissic host rock and reveals more significant changes in $\mathrm{SO}_{4}$, alkalinity, base cations and $\mathrm{pH}$. The MK60 borehole revealed significant hydrochemical changes, similar to those in BP08, despite not intersecting a major contact zone. The Quaternary geology, with the presence of wetlands, was observed to be of importance to the hydrochemical changes although the presence of fracture minerals such as pyrite was found to be the dominant factor. 
Pyrite oxidation and calcite dissolution were explored further in a separate study (Mossmark et al. 2015b) in which hydrochemical modelling was carried out. This work included the replication of hydrochemical processes and hydrological patterns in order to replicate the situation in the study area. This study supports the assumption of a greater abundance of pyrite in the vicinity of the MK60 borehole compared to at the MK56 borehole.

The hydrochemical conditions are, among other things, the result of a number of naturally occurring chemical processes. The different relevant processes occur during a variety of time frames and the hydrological changes could thus result in processes that take longer to diminish in importance. In crystalline bedrock, in which calcite is marginal or absent, silicate weathering is commonly of importance to the hydrochemical conditions and especially as a contributor to alkalinity (Appelo and Postma 2005). However, this is a slow process (the time frame is from days to years), and its importance is marginalised by the shortened residence time of the groundwater.

It was noted that the groundwater levels recovered completely in MK56 and BP08 after the western tunnel had been successfully waterproofed. However, the groundwater levels in MK60 remained slightly affected (0.1-0.5 m below the pre-construction conditions). The impact on the hydrochemistry was observed to have a longer duration compared to the impact on the groundwater levels and the duration of the hydrochemistry varies between the different measured parameters. For $\mathrm{Fe}$ and $\mathrm{Mn}$, the recovery was more rapid than for the major cations and anions. The latter are assessed to require several years for full recovery to unaffected concentrations. These observations confirm results from previous studies, such as Mossmark et al. (2008) and Kværner and Snilsberg (2013).

\section{Implications for construction materials}

The redox potential increased in the groundwater level in each of the three boreholes although the changes in other parameters that are of importance for the durability of construction materials differed significantly. For these parameters (primarily $\mathrm{SO}_{4}$, alkalinity, and $\mathrm{pH}$ ), water in MK56 exhibited less significant changes than in MK60 and BP08.

\section{Steel-based construction materials}

Corrosion indices have been calculated in order to evaluate the implications for steel-based construction materials. The Larson-Skold Index (Larson and Skold 1958) was established to assess the corrosivity of water in steel pipes, see equation below.
Larson-Skold Index $=\frac{\mathrm{epmSO}_{4}^{2-}+\mathrm{epmCl}^{-}}{\mathrm{epmHCO}_{3}^{-}+\mathrm{epmCO}_{3}^{2-}}$,

where epm represents equivalents per million. If the Larson-Skold Index is below 0.8 , the water is considered noncorrosive. If the Index is $0.8-1.2$, it is likely that a corrosion rate that is higher than desired will occur. If the Index is greater than 1.2, higher corrosion rates with an increasing ratio are expected.

Figure 15 shows the Larson-Skold Index for the groundwater in the three boreholes in the bedrock. According to the Larson-Skold Index, the water in MK56 was non-corrosive. For the other two boreholes, a sharp increase could be seen at the time the groundwater levels recovered in early 2012. Before tunnel construction using a TBM in the vicinity of the study area, the water was more corrosive in BP08 than in MK60. However, during the recovery of the groundwater levels following construction of the western tunnel, the Larson-Skold Index increased more significantly in MK60 than in BP08.

Calculations of the Ryznar (1944) and Langelier (1936) Indices confirm that the changes were more significant for BP08 and MK60 compared to MK56. The Langelier Index was between -1 and -3 while the Ryznar Index varied between 9 and 12. Furthermore, they indicate a slightly less corrosive environment in MK56 compared to the other two boreholes. The indices show that calcite formation is unlikely and that the environment, both before and during the construction period, is slightly corrosive.

Increasing $\mathrm{SO}_{4}$ concentrations are the main factor behind the high Larson-Skold Index in MK60 and BP08. The increased corrosivity according to the Langelier index is based on decreasing $\mathrm{pH}$. $\mathrm{Cl}$ concentrations remained fairly stable in the three boreholes during the monitoring periods. However, the changes in redox, which indicate the possibility of water with dissolved oxygen reaching steel materials near a tunnel, are not included in the corrosion indices.

\section{Cement-based materials}

According to industry standard EN206-1 (European standards for concrete 2000), high concentrations of $\mathrm{SO}_{4}, \mathrm{Mg}$, and aggressive $\mathrm{CO}_{2}$, as well as low $\mathrm{pH}$ are detrimental to the durability of concrete. The standard has established three exposure classes for groundwater, XA1, XA2, and $\mathrm{XA} 3$, with XA3 being the most aggressive environment.

Before construction with the TBM began, the groundwater in the three monitored boreholes would have been considered non-aggressive according to EN206-1. However, during construction of the eastern and western tunnels, the hydrochemistry in BP08 and MK60 reached the lowest exposure class, XA1, on several occasions. For 
Fig. 15 Larson-Skold Index for groundwater in the three monitored boreholes. The groundwater in two of the boreholes was assessed to have become more corrosive to steel

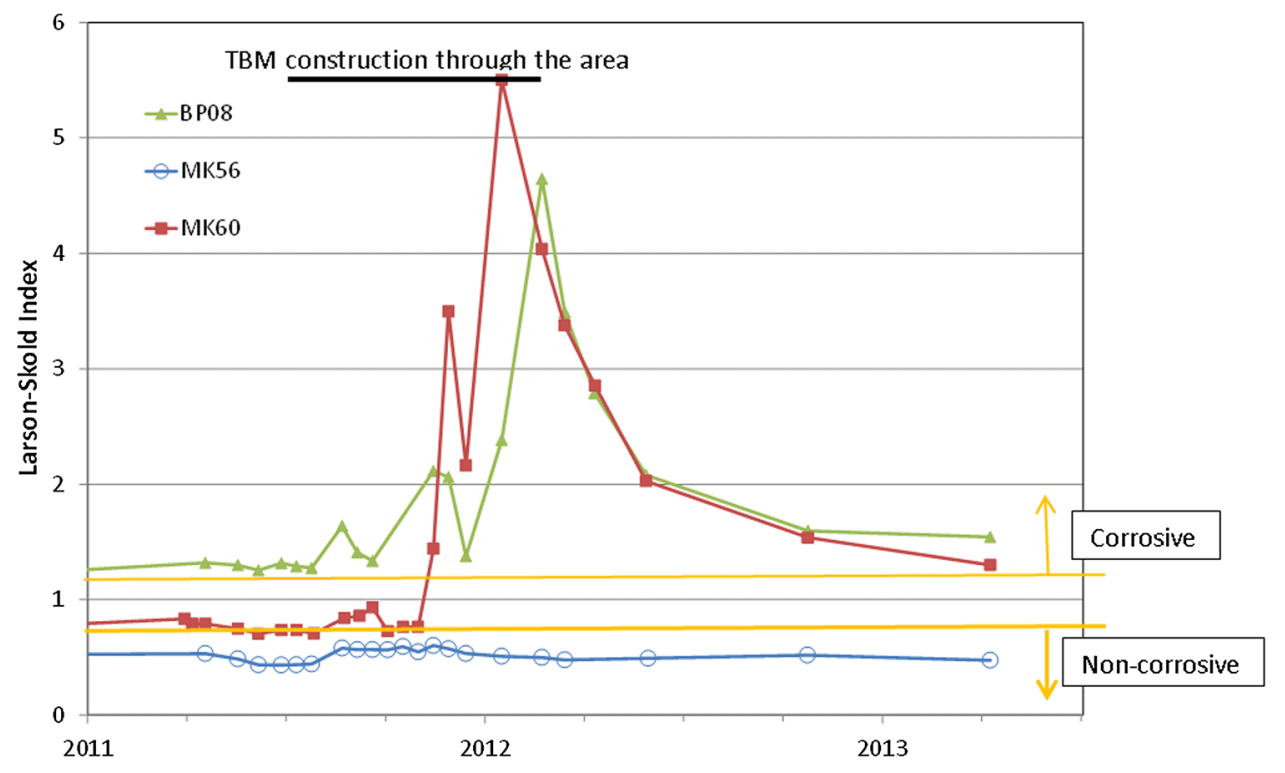

MK60, a low pH (below 6.5) caused the water to be characterised as XA1 for several consecutive sampling occasions for 6 months in late 2011 and early 2012. For BP08, a pH below 6.5 and $\mathrm{SO}_{4}$ concentrations above $200 \mathrm{mg} / \mathrm{L}$ caused the water to be considered aggressive on two occasions. During construction of the western tunnel, the groundwater in BP08 would have been considered as exposure class XA2 on one sampling occasion. MK56 remained within the non-aggressive range (below XA1) throughout the monitoring period. The hydrochemistry in BP08 and MK60 recovered to return to a non-aggressive state after tunnelling activities with the TBM were completed within the study area.

The standard EN206-1 reflects the degrading mechanisms of cement-based materials. For $\mathrm{SO}_{4}$, the primary processes include the formation of ettringite, thaumasite, and gypsum (Santhanam et al. 2002). According to laboratory results presented by Revertegata et al. (1992), low $\mathrm{pH}$ is related to leaching of $\mathrm{Ca}$. Field studies dealing with the degradation of concrete have confirmed the combined effects of low $\mathrm{pH}$ and high $\mathrm{SO}_{4}$ concentrations (Bellmann et al. 2012).

\section{Tunnel drainage systems}

Drainage systems in tunnels are prone to clogging and thus frequent dysfunction with resulting high maintenance costs (Lindblom 2010). According to Ekliden (2008), the drainage systems in tunnels are frequently clogged by chemical precipitation and biological activities. The Hallandsås tunnels are lined through the study area and are virtually waterproof. Consequently, this discussion focuses on the implications for tunnels with a drainage system (not the current project).
Common processes are the precipitation of $\mathrm{Mn}$ and $\mathrm{Fe}$, as well as the formation of $\mathrm{CaCO}_{3}$ and these are of importance for the potential clogging of the drainage system. However, the same processes may contribute to temporarily decreasing seepage volumes. The results from the monitoring showed decreasing concentrations of dissolved $\mathrm{Fe}$ and $\mathrm{Mn}$ during the construction phase of the western tunnel. This indicates that the increased redox potential caused $\mathrm{Fe}$ and $\mathrm{Mn}$ to precipitate in the bedrock. However, the concentrations recovered within a few months following construction with the TBM and successful waterproofing of the tunnel through the area.

The tunnelling activities increased the concentrations of dissolved $\mathrm{Ca}$ in the bedrock groundwater with $\mathrm{CaCO}_{3}$ being dissolved to neutralise $\mathrm{H}$. With degassing of $\mathrm{CO}_{2}$ at the tunnel wall and inside the drainage system, $\mathrm{Ca}$ is likely to once again precipitate as $\mathrm{CaCO}_{3}$. This may cause a drainage system to clog. If the tunnel was not lined, higher water influx would probably have remained during the operational phase of the tunnel. This may also have resulted in prolonged periods of elevated concentrations of $\mathrm{Ca}$ in the bedrock groundwater and a greater likelihood of clogging of the drainage system.

\section{Conclusions}

The hydrochemistry of shallow water, as well as groundwater in the overburden and bedrock were affected by the construction of the western tunnel. The observed hydrochemical changes were the result of changes in water flow driven by seepage into the tunnels and the chemical processes that were subsequently induced. 
The most important hydrochemical changes to the surface waters due to seepage into the tunnel were (a) lower ionic strength (diminished discharge), (b) $\mathrm{SO}_{4}$ surges from the wetlands, and (c) absence of or lower alkalinity and lower $\mathrm{pH}$ (combined/alternating effect of the above-mentioned changes). For the shallow water, the magnitude of the hydrochemical changes varied between the sampling points and was affected by the proportion of the relative decrease in groundwater discharge.

The hydrochemical changes in deep groundwater in the bedrock differed between the three monitored boreholes. The geological conditions were the most important factor behind the differences. However, some results were universal for all monitored boreholes:

- Increasing redox potential was observed in all three monitored boreholes during drawdown of the groundwater level.

- The solubility of Fe and Mn decreased temporarily.

- Increased presence of organic matter although degradation (oxidation) of organic matter did not reduce Fe or Mn significantly into soluble species.

- The redox potential recovered after the waterproofing system of the tunnel was installed.

- Two of the three boreholes revealed significant hydrochemical changes for the major ions. The two boreholes were in relatively fractured bedrock with the presence of pyrite. The hydrochemical changes were caused primarily by hydraulic connections to shallow water and by the oxidation of pyrite. The changes included the following:

- $\mathrm{SO}_{4}$ concentrations increased more than fivefold.

- Lowering of $\mathrm{pH}$ and alkalinity.

- Changes in major cations.

- The third borehole revealed changes of less magnitude to the major anions, cations, and $\mathrm{pH}$. The concentrations of $\mathrm{SO}_{4}$ increased by approximately $50 \%$. This borehole penetrates gneissic rock with few fractures, hence the absence of contact zones and less hydraulic contact with shallow water. Pyrite was not observed during the drilling of this borehole.

- The presence of a dolerite dyke that comprised a negative hydraulic boundary between the two aquifers shortened the period of affected groundwater levels in the third borehole and recovery was observed during the monitoring period. However, the hydrochemical impact from the tunnelling was observed to have a longer duration.

- Slow processes, such as silicate weathering, became less significant because of a shorter residence time for the groundwater compared to unaffected conditions.
Silicate weathering is an important contributor to alkalinity in crystalline bedrock, thus decreasing buffer capacity against acidification. This contributed to the temporary decrease in alkalinity in the bedrock groundwater during the period with affected groundwater levels.

According to corrosion index calculations, the groundwater in the two boreholes that revealed most hydrochemical changes became corrosive to steel construction materials. The corrosivity decreased gradually alongside recovery of the hydrochemistry. Similar interpretations were valid for cement-based materials based on exposure class standards. During periods of high $\mathrm{SO}_{4}$ and low $\mathrm{pH}$, the demands made on the properties of the selected cementbased construction materials increased according to standard EN 206-1 (water-cement ratio).

The borehole loggings showed significant hydrochemical depth variations, highlighting the difficulties encountered when collecting groundwater samples that are representative for the entity of interest. Furthermore, the results confirm the conclusions from previous studies that recovery from hydrochemical changes caused by underground constructions takes longer compared to the recovery of groundwater levels.

Acknowledgements Financial support for the research presented in this paper has been received from the Development Fund of the Swedish Construction Industry, SBUF. The Swedish Transport Administration at Hallandsås provided support on site, which proved invaluable to the success of this research project. Many thanks also to Martin Werner and Aron Bodén for support with the fieldwork. The research presented in this article was carried out in collaboration with the TRUST-Transparent Underground Structure-platform.

Open Access This article is distributed under the terms of the Creative Commons Attribution 4.0 International License (http://crea tivecommons.org/licenses/by/4.0/), which permits unrestricted use, distribution, and reproduction in any medium, provided you give appropriate credit to the original author(s) and the source, provide a link to the Creative Commons license, and indicate if changes were made.

\section{References}

Åhäll K-I, Gower CF (1997) The Gothian and Labradorian orogens: variations in accretionary tectonism along a late Paleoproterozoic Laurentia-Baltica margin. GFF 119:181-191

Annertz K (2009) Projekt Hallandsås, Geologi, Underlagsrapport för ny tillståndsansökan, Swedish Rail Administration (in Swedish)

Appelo CAJ, Postma D (2005) Geochemistry, groundwater and pollution. CRC Press, USA

Bellmann F, Erfurt W, Ludwig H-M (2012) Field performance of concrete exposed to sulphate and low $\mathrm{pH}$ conditions from natural and industrial sources. Cem Concr Comp 34(1):86-93

Borca T (2007) Hallandsås-Sweden's most environmentally controlled Construction Project. Aufbereitungs-Technik (Mineral Processing) 48(6):26-36 
Chiu Y-C, Chia Y (2012) The impact of groundwater discharge to the Hsueh-Shan tunnel on the water resources in northern Taiwan. Hydrogeol J 20(8):1599-1611

Dahlin T, Bjelm L, Svensson C (1999) Use of electrical imaging in site investigations for a railway tunnel through the Hallandsås Horst, Sweden. Q J Eng Geol 32:163-172

Danielsen, B E (2010). The Applicability of Geoelectrical Methods in Pre-Investigation for Construction in Rock. Doctoral thesis, Lund University

Danielsen BE, Dahlin T (2009) Comparison of geoelectrical imaging and tunnel documentation at the Hallandsås Tunnel, Sweden. Eng Geol 107(3-4):118-129

Danielsen BE, Madsen HB (2013) Resistivity logging as a tool for identifying initial weathering in crystalline rocks. Near Surf Geophys 11(3):353-362

Ekliden J (2008) Igensättning av dräner i bergtunnlar (in Swedish). Master thesis. Gothenburg University. Gothenburg, Sweden

Eklund HS (2001). Hydrogeologiska typmiljoer: verktyg for bedömning av grundvattenkvalitet, identifiering av grundvattenförekomster samt underlag for riskhantering längs vägar (in Swedish). Licentiate thesis. Chalmers University of Technology. Gothenburg, Sweden

European standards for concrete (2000) EN 206-1, Concrete: Specification, performance, production and conformity. European Committee for standardization, Brussels

Giblin A, Wieder K (1992) Sulphur cycling in marine and freshwater wetlands. In: Howart RW, Stewart JWB, Ivanov MV (eds) Sulphur Cycling on the Continents. Wiley, pp 85-117

Gustafson G (2012) Hydrogeology for rock engineers. BeFo, Rock engineering research foundation, Sweden

Gynnemo M (2009) Ytvattenpåverkan 2006-2009, Underlagsrapport för ny tillståndsansökan Hallandsås, Swedish Rail Administration (in Swedish)

Jones M (2010) Hallandsås First Drive Approaches End. Tunnels and Tunnelling International, May 28-31

Kitterød NOK, Colleuille HC, Wong WW, Pedersen TP (2000) Simulation of groundwater drainage into a tunnel in fractured rock and numerical analysis of leakage remediation, Romeriksporten tunnel, Norway. Hydrogeol J 8(5):480-493

Kottek M, Grieser J, Beck C, Rudolf B, Rubel F (2006) World Map of the Köppen-Geiger climate classification updated. Meteorol Z 15:259-263

Kværner J, Snilsberg P (2013) Hydrogeological impacts of a railway tunnel in fractured Precambrian gneiss rocks (south-eastern Norway). Hydrogeol J 21:1633-1653

Kvartsberg S (2013) On the use of engineering geological information in rock grouting design. Chalmers university of technology, publ. lic. 2013:8

Langelier WF (1936) The analytical control of anticorrosion water treatment. J AWWA 28:1500-1521

Larson TE, Skold RV (1958) Laboratory studies relating mineral water quality of water on corrosion of steel and cast iron. Corrosion 14(6):285-288

Lindblom U (2010) Bergbyggnad (in Swedish). Liber, Stockholm
Lindström M, Lundqvist J, Lundqvist T (2000) Sveriges geologi från urtid till nutid (in Swedish). Studentlitteratur

Mathurin FA, Åström ME, Laaksoharju M, Kalinowski BE, Tullborg E-L (2012) Effect of tunnel excavation on source and mixing of groundwater in a coastal granitoidic fracture network. Environ Sci Technol 46(23):12779-12786

Mossmark F (2010) Groundwater chemistry affected by underground constructions. Publ. Lic 2010:2. Chalmers University of Technology. Gothenburg

Mossmark F (2014) Prediction of groundwater chemistry in conjunction with underground construction - field studies and hydrochemical modelling. $\mathrm{PhD}$ thesis 3802, Chalmers university of technology

Mossmark F, Hultberg H, Ericsson LO (2007) Effects on water chemistry of groundwater extraction from crystalline hard rock in an acid forested catchment at Gårdsjön, Sweden. Appl Geochem 22:1156-1157

Mossmark F, Hultberg H, Ericsson LO (2008) Recovery from an intensive groundwater extraction in a small catchment with crystalline bedrock and thin soil cover in Sweden. Sci Total Environ 404(1-3):253-261

Mossmark F, Ericsson LO, Norin M, Annertz KK, Dahlström L-O (2010) Groundwater and hydrochemical interaction with underground constructions - experience from Hallandsåsen. In: Proceedings of rock mechanics in the Nordic countries 2010. Kongsberg, Norway

Mossmark F, Ericsson LO, Norin M, Dahlström L-O (2015a) Hydrochemical changes caused by underground constructions-a case study of the Kattleberg rail tunnel. Eng Geol 191:86-98

Mossmark F, Ericsson LO, Palm F (2015b) Simulations of hydrochemistry affected by tunnelling in crystalline bedrock. In: Proceedings of Modflow and More conference 2015, Colorado School of Mines

Norling E, Bergström J (1987) Mesozoic and Cenozoic tectonic evolution of Scania, southern Sweden. Tectonophysics 137(1-4):7-19

Olofsson B (1991) Impact on groundwater conditions by tunnelling in hard crystalline rocks. Doctoral thesis. Royal Institute of Technology, Stockholm

Revertegata E, Richeta C, Gégoutb P (1992) Effect of pH on the durability of cement pastes. Cem Concr Res 22(2-3):259-272

Ringberg B (2000) Map of the Quaternary Deposits 4C Halmstad SV. Swedish geological survey, series Ae no 121

Ryznar JW (1944) A new index for determining amount of calcium carbonate formed by water. J AWWA 36:472-486

Santhanam M, Cohen MD, Olek J (2002) Mechanism of sulfate attack: a fresh look-Part 1: summary of experimental results. Cem Concr Res 32:915-921

Sturk R, Dudouit F, Aurell O, Eriksson S (2011) Summary of the first TBM drive at the Hallandsås project. In: Proceedings-Rapid Excavation and Tunneling Conference, San Francisco, United States; June 19-22, 2011 